\title{
What and how do SMEs gain by going international? A longitudinal investigation of financial and intellectual resource growth
}

\begin{abstract}
This study examines the accumulation of financial and intellectual resources of U.S.-based biopharmaceutical SMEs. We find that internationalized SMEs experience better financial resource growth than domestic market-focused SMEs only in the long run. While international expansion per se does not enable SMEs to accumulate more intellectual resources than via domestic expansion, it exerts a positive impact over time for SMEs with strong alliance capabilities. Moreover, we show that alliance capabilities are more important than in-house technological capabilities for key resource accumulation of internationalized SMEs over time. Our results infer that SMEs gain the benefits of resource exploration via international expansion.
\end{abstract}

\section{Keywords:}

Internationalization; dynamic capability; technological capability; alliance capability; SME;

biopharmaceutical industry 


\section{Introduction}

International expansion has become an increasingly common strategic option for small and medium-sized enterprises (SMEs), even those based in large domestic markets, despite the conventional belief that they are particularly vulnerable in foreign markets due to their inherent resource constraints (Knight \& Cavusgil, 2004; Love \& Roper, 2015). Extant literature indicates that SMEs could exploit their limited resources and capabilities such as marketing skills, technological competencies, and partnering capabilities to perform successfully in the international arena (Dhanaraj \& Beamish, 2003; Hessels \& Parker, 2013; Lu \& Beamish, 2001; Sui \& Baum, 2014). SMEs could also explore new resources and capabilities such as foreign market-specific knowledge and innovative product development routines to strive for long-term growth (Eriksson, Fjeldstad, \& Jonsson, 2017; Zhou, Barnes, \& Lu, 2010; Zhou \& Wu, 2014).

In light of Penrose's (1959) theory of the growth of the firm (TGF), however, both international business and strategy scholars tend to agree that SMEs' growth options are constrained in large part due to their small size (Cavusgil \& Knight, 2015; Knight \& Cavusgil, 2004; Verwaal \& Donkers, 2002; Zollo \& Winter, 2002). Ideally, SMEs would expand their operations both at home and abroad; in reality, however, SMEs - especially those operating in sizable home markets - tend to be wary of the latter approach due to the anticipated joint liabilities of smallness and foreignness (Kirca et al., 2011) or the potential disruption to internal consistency of their domestic organization resulting from the need to adapt to foreign environments (Lampel \& Bhalla, 2011). ${ }^{1}$ Further, SMEs may try to exploit and explore their resources and capabilities to survive and grow over time. In practice, however, SMEs typically have to focus either on exploitation or exploration within a particular period of time given their limited managerial resources (Zollo \& Winter, 2002).

The argument above raises two important questions: first, if some SMEs still choose to go international despite the anticipated liabilities of operating in the international arena, what do they gain

\footnotetext{
${ }^{1}$ It should be noted that SMEs from small and open economies may struggle for survival without international markets. For them, international expansion may be a necessity instead of an option.
} 
through international expansion (as opposed to domestic expansion) over time? Second, how do internationalized SMEs gain considering that they are small and tend to face the trade-off between resource exploitation and exploration?

To address these questions, we focus on a research-intensive industry (i.e., the biopharmaceutical industry) to investigate longitudinally the accumulation of financial and intellectual (i.e., knowledge-based) resources, both of which are critical for SMEs in such an industry in light of resource exploitation and exploration (Mangematin, Lemarie, Boissin, Catherine, Corolleur, Coronini, \& Trommetter, 2003). Our emphasis on the temporal or longitudinal effect (Shi, Sun, \& Prescott, 2012) on key resource development departs from the extant literature which largely pays attention to internationalization speed, timing, and performance implications thereof (Chetty, Johanson, \& Martín, 2014; Hilmersson \& Johanson, 2016; Jiang, Beamish, \& Makino, 2014; Vermeulen \& Barkema, 2002; Zhou \& Wu, 2014). Moreover, we suggest that the recent advance of the dynamic capabilities-based perspective in the IB literature indicates clearly that young and internationalized SMEs need to develop new capabilities to identify and respond quickly to opportunities to accelerate their expansion and enhance competitiveness (Teece, 2014; Weerawardena, Mort, Liesch, \& Knight, 2007; Zhou et al., 2010). Thus, we anticipate that internationalized SMEs in research-intensive industries may seek to explore new resources (or acquire new knowledge) in the short to medium run in their international expansion as they face a dynamic and complex global environment (Zahra, Ireland, \& Hitt, 2000).

For SMEs in research-intensive industries, the importance of both in-house technological capabilities (i.e., R\&D) and alliance capabilities has been stressed (Love \& Roper, 2015; Partanen, Moller, Westerlund, Rajala, \& Rajala, 2008; Weerawardena et al., 2007). Both capabilities are delineated as innovative capabilities within the framework of dynamic capabilities articulated by Teece (2014). However, since one is internally while the other externally focused on growing and augmenting firm resources, their roles must be different. This is especially relevant for internationalized SMEs that have to cope with environmental diversity and organizational complexity (Verbeke, Li, \& Goerzen, 2009). Thus, this study examines specifically whether SMEs accumulate effectively financial and intellectual resources through 
international expansion as opposed to domestic expansion and how they grow these resources by leveraging in-house technological and alliance capabilities over time.

Overall, the temporal approach we adopt for this study sheds new light on the value of multinationality (i.e., what is to be gained) for SMEs that face the joint liabilities of smallness and foreignness thereby enabling relevant inferences on why some SMEs are motivated to go international. Moreover, our investigation generates insight into how SMEs benefit from international expansion. Specifically, we make three contributions to the literature; first, we theorize and empirically demonstrate that internationalized SMEs face a prolonged liability of foreignness when it comes to augmenting their resources and capabilities despite the intrinsic value of multinationality. Our findings show that international expansion is not superior to domestic expansion in terms of financial resource accumulation in the short to medium run. Only in the long run, internationalized SMEs experience better financial resources growth than their domestic counterparts. Our findings are robust even after accounting for the roles of in-house technological and alliance capabilities. This is a novel finding given that prior studies are either cross-sectional or exclude comparison with domestic firms (Verbeke \& Forootan, 2012) enriching, therefore, the existing literature on motivation, processes, and consequences of international expansion.

Second, our examination of SMEs' intellectual resource growth qualifies and extends Penrose's TGF in the context of international versus domestic expansion. At first glance, our findings reinforce Penrose's argument that firm growth in the domestic market could be equally (if not more) effective in accruing intellectual resources over time as compared to international growth for SMEs based in a large and advanced economy (Penrose, 1995). However, further examination of the temporal differences of resource accumulation along the international and domestic growth paths indicates that alliance capabilities enable superior long-term intellectual resource accumulation by internationalized SMEs as compared to domestic ones whereas in-house technological capabilities exert a positive impact only in the short run. This infers that international expansion of SMEs in research-intensive industries benefits SMEs' resource exploration more than exploitation over time and that alliance capabilities facilitate that process. 
Third, we refine and advance the dynamic capabilities-based perspective of the multinational enterprise (MNE). Teece (2014, p.26) argues that "asset augmentation comes fundamentally from R\&D and learning process, whether internal or from partners..." Our study reveals that alliance capabilities are more potent over time as compared to in-house technological capabilities in accruing intellectual resources and, to a lesser extent, financial resources for internationalized SMEs. In line with Zollo and Winter's (2002) reasoning, alliance capabilities are arguably more representative of dynamic capabilities than inhouse technological capabilities considering the need for firms to keep adapting to different partners in a dynamic and complex global environment.

\section{Theoretical underpinnings}

In the preface to the 1995 edition of her seminal book "Theory of the Growth of the Firm", Penrose indicates that the raison d'etre of MNEs applies equally to domestic firms expanding within the U.S. or other large countries. This implies that international and domestic expansion strategies of SMEs may be comparable as well if these firms are based in large domestic markets. Yet, previous studies are most often concerned with possible SME internationalization paths and short-term profitability while ignoring domestic growth and long-term performance (Kuivalainen, Sundqvist, \& Servais, 2007; Sui \& Baum, 2014). In our discussions with a number of senior executives of U.S. biopharmaceutical SMEs conducted in preparation for this study, however, it was stressed repeatedly that internationalization is not always the preferred resource growth path if the SME is based in a large, domestic economy where attractive alternatives exist, especially given the liabilities of operating in the international arena. This indicates that scholars and practitioners may be overlooking or downplaying the roles of international scope and diversity in firm growth. In addition, whether through domestic or international growth paths, it is innovative capabilities in the sense of discovering productive opportunities and creating knowledge that are essential for SMEs to accumulate financial and intellectual resources (Penrose, 1995; Pitelis, 2002).

We contend that innovative capabilities, as expressed by Teece (2014), refer to a combination of internal organization-based capabilities (Teece, Pisano, \& Shuen, 1997) and externally oriented alliance capabilities (Dhanaraj, Lyles, Steensma, \& Tihanyi, 2004; Simonin, 2004). More specifically, internal 
capabilities are mainly in-house technological capabilities relating to R\&D activities (Buckley \& Casson, 2007) which are critical for firm growth in research-intensive industries because they direct firms to new products and markets thereby enhancing their financial and intellectual resources. It is particularly so when competition focused on innovation through $R \& D$ is intense, as in the biopharmaceutical industry. This suggests that SMEs with stronger in-house technological capabilities are more likely to accrue key productive resources such as financial and intellectual resources.

Alliance capability, a firm's skill in getting access to external resources owned or controlled by other firms, is an essential capability in research-intensive industries (Mangematin et al., 2003; Partanen et al., 2008). Schilke and Goerzen (2010) define alliance capability as a distinct dynamic capability, emphasizing learning routines that generate new knowledge and build new thinking. In fact, the literature shows ample evidence that alliances are critical for enhancing organizational learning (Eisenhardt \& Schoonhoven, 1996; Mowery, Oxley, \& Silverman, 1996) and have become an "admission ticket to new innovations" (Oliver, 2001, p.470). In addition, alliance capabilities provide positive signals to investors in research-intensive industries such as the biopharmaceutical industry (Mangematin et al., 2003).

In the international arena, alliance capabilities are especially important for SMEs in researchintensive industries to attract and grow financial and intellectual resources for several reasons (Barkema, Shenkar, Vermeulen, \& Bell, 1997; Eisenhardt \& Schoonhoven, 1996). First, SMEs with strong alliance capabilities typically have developed learning mechanisms and routines which are embodied in their functional and business processes and are particularly useful during firm international expansion (Kale \& Singh, 2007). Heimeriks and Duysters (2007), for example, find that strong alliance capabilities lead firms to develop cultural sensitivity programs and country-specific collaborative policies. Second, alliance capabilities hone three different skill sets over time: coordination, communication, and relationship building (Schreiner, Kale, \& Corsten, 2009). These skill sets facilitate the accrual of financial and intellectual resources of SMEs, especially those operating in the international arena wherein diversity of potential partners may impose significant managerial challenges resulting in part from the liability of outsidership (Johanson \& Vahlne, 2009; Verwaal \& Donkers, 2002). Although the two drivers of resource growth noted 
above, i.e., in-house technological and alliance capabilities, are both important, we still do not understand how they affect SME financial and intellectual resource growth in the international versus domestic market context which this study seeks to address as reflected in Figure 1.

$$
\text { ***Insert Figure } 1 \text { about here*** }
$$

\section{Hypotheses development}

\subsection{SME financial resource growth}

Prior research has shown that growth based on a balance between exploitation of existing capabilities and the development of new ones is financially beneficial to firms (Penrose, 1995; Rugman \& Verbeke, 2002). Given resource constraints, however, SMEs tend to view international expansion differently than large firms do and they often respond by following varying processes of internationalization and/or trying to be flexible when they expand overseas (Cerrato, Crosato, \& Depperu, 2016; Li, Li, \& Dalgic, 2004; Verwaal \& Donkers, 2002). Moreover, it is not obvious whether international expansion leads to better financial resource accumulation than domestic growth for SMEs based in large home countries in light of Penrose's TGF.

We argue that the financial benefits of SME internationalization exist only in the long run for three reasons. First, SMEs face joint liabilities of smallness and foreignness, especially in the early stage of internationalization (Kirca et al., 2011). Second, SMEs are under strong influence of time compression diseconomies in establishing and expanding their foreign operations (Jiang et al., 2014; Shi \& Prescott, 2012) and thus may struggle with the disruption to their domestic organizational configuration resulting from the need to adapt to foreign environments (Lampel \& Bhalla, 2011). Third, although recent IB literature stresses the possible learning advantages of young (and typically small) international firms (Hilmersson \& Johanson, 2016; Weerawardena et al., 2007), scholars point out that resource/knowledge exploration has uncertain consequences prior to knowledge articulation and codification in the short to medium run (Zollo \& Winter, 2002).

To realize the long-term growth of financial resources, therefore, two basic conditions need to be satisfied. First, there must be sufficient productive opportunities and external resources available. Second, 
a firm must possess dynamic capabilities to exploit and explore relevant opportunities and for deploying, integrating, and reconfiguring both internal and external resources. Regarding the first condition, a prima facie argument is that a large and diverse home country tends to provide ample productive opportunities and abundant financial resources for SMEs so that internationalization may not be optimal or even necessary. Even if internationalized SMEs could take advantage of the broader range of opportunities and greater pool of external resources owing to a larger and more diverse arena in which they operate, they would be hampered by the increased costs of doing business abroad in the early stage of internationalization (Lu \& Beamish, 2001). Further, although internationalized SMEs may escape domestic rivalry by choosing to capitalize on the opportunities and resources in potentially less competitive markets abroad, it is likely that they would face many challenges abroad given the increasingly intense competition among firms in the international arena.

Our overall proposition, therefore, is that for SMEs based in large home countries international expansion per se may not be inherently superior to domestic expansion and, thus, may not lead to stronger financial resources growth (or more financial benefits) in the short run. In the longer term, however, the situation may be significantly different. While both large domestic and international markets can offer productive opportunities and external resources, those from international markets are typically more diverse (McDougall \& Oviatt, 2000). The more diverse market conditions and customer demands naturally present a richer environment for internationalized SMEs so that they can learn to deploy their existing dynamic capabilities (i.e., the second condition noted above) to exploit and, perhaps more importantly, explore resources in a wide range of areas over the long run. Moreover, since opportunities do not exist in vacuum, one could argue that the value of opportunities resides in an SME's relative skill set since opportunities can only be interpreted in the joint consideration of market and capabilities (Di Gregorio, Musteen, \& Thomas, 2008). Although internationalized SMEs could face a significant liability of foreignness and liability of outsidership in the early stage of international expansion, the costs associated with both would decline over time with the continual increase of international market knowledge and experience. Thus, given the availability of more diverse opportunities and external resources, internationalized SMEs may learn over 
time to make more effective use of their capabilities for firm financial resource growth as compared to their domestic counterparts, leading to our first hypothesis:

Hypothesis 1: Internationalized SMEs achieve superior financial resource growth over time as compared to their domestic market-focused counterparts.

We argue further that in-house technological capabilities can strengthen this positive relationship between an SME's international expansion and long-term financial resource growth. Rugman and Verbeke (2003) articulate the importance of combining firm-specific advantages with country-specific advantages (or resources) for MNEs to expand and operate effectively in the international arena over time. This suggests that more diverse opportunities and more external resources in foreign countries may be leveraged over time to bring more financial benefits to internationalized SMEs with strong firm-specific capabilities. Relevant IB research indicates specifically that in-house technological capabilities may be transferred and deployed in the broader international markets to generate greater economic value as a result of the scope effect (Lu \& Beamish, 2004; Morck \& Yeung, 1991). In a similar vein, Teece (2014) notes that the incremental costs of international expansion are likely to be low for firms with strong ordinary and dynamic capabilities because these capabilities are needed for making necessary adjustments in foreign countries. Thus, we propose that internationalized SMEs' financial resources grow more significantly over time when they possess stronger in-house technological capabilities, leading to our second hypothesis:

Hypothesis 2: Internationalized SMEs with stronger in-house technological capabilities achieve much superior financial resource growth over time as compared to their domestic market-focused counterparts.

The literature on alliance capabilities indicates that "cross-border alliances can extend the range of partnering benefits relative to alliances with domestic partners by bridging national boundaries and leveraging a firm's competitive advantage in foreign markets" (Lavie \& Miller, 2008, p.625). Foreign alliances not only reduce financial outlays but also enhance MNE access to local resources over time (Teece, 2014). In research-intensive industries, almost all SMEs strive to form alliances to gain access to critical resources (Mangematin et al., 2003). Notwithstanding, the partnering benefits are difficult to materialize in the early stage of international expansion because SMEs incur high costs initially to establish governance structures for dealing with foreign partners (Verwaal \& Donkers, 2002) and it takes time to 
develop the new operational routines for foreign alliances (Zollo \& Winter, 2002). Only after overcoming the initial challenges of relationship building would internationalized SMEs gradually gain access to new resources including the scientific community and leading research facilities, thereby enhancing their visibility through foreign alliances. Networking in the international arena would help to improve the level of trust among financial institutions and investors that facilitate the acquisition of capital and other financial resources (Partanen et al., 2008). Thus, stronger alliance capabilities would drive more financial resource growth over time for internationalized SMEs, as per our next hypothesis:

Hypothesis 3: Internationalized SMEs with stronger alliance capabilities achieve much superior financial resource growth over time as compared to their domestic market-focused counterparts.

\subsection{SME intellectual resource growth}

For SMEs in research-intensive industries, intellectual resource growth is crucial. It is unclear in the literature, however, whether SMEs grow intellectual resources differently through internationalization than via domestic expansion. We argue that internationalized SMEs can achieve superior intellectual resource growth as compared to their domestic market-focused counterparts over time. The benefits are substantial when SMEs manage to acquire complementary knowledge resulting from national differences in an effort to cope with resource constraints and competitive disadvantages (Knight \& Cavusgil, 2004). SMEs, in the short run, have to learn to locate and investigate opportunities and to develop new capabilities or acquire new knowledge in an unfamiliar context. Thus, the benefits from cross-border knowledge application and development would not readily accrue to SMEs which lack international experience and, thereby, face the liability of foreignness. Moreover, there is greater uncertainty in knowledge exploration in the cross-border context in part because of the cognitive and normative barriers across nations (Verwaal, 2017) and in part because it takes time to articulate and codify the newly acquired/developed knowledge to reap the intellectual benefits (Zollo \& Winter, 2002). In the longer run, however, SMEs tend to become more effective in discovering and capitalizing on lucrative opportunities and knowledge assets in foreign countries with gradual decline of the liability of foreignness. This leads to our next hypothesis:

Hypothesis 4: Internationalized SMEs achieve superior intellectual resource growth over time as compared to their domestic market-focused counterparts. 
How effective internationalized SMEs are at finding foreign opportunities to explore and accumulate intellectual resources depends on whether they possess strong in-house technological capabilities (Weigelt \& Sarkar, 2012). Host country-specific factors can be important only when a firm has the capabilities to access local advantages (Teece, 2014). SMEs' capacities for exploring external opportunities by leveraging in-house technological capabilities may be strained, however, in foreign countries in the short to medium term due to different geographic and institutional contexts which tend to increase the difficulty of transferring management skills, thereby eroding the applicability of in-house technological capabilities (Barkema et al., 1997). The challenges resulting from unfamiliar contexts decline over time, however, as firms gain international experience (Lu \& Beamish, 2004) and develop new knowledge in the distinct host-country environments (Teece, 2014). Thus, we posit that SMEs' in-house technological capabilities strengthen the positive relationship between internationalization and intellectual resource accumulation over time, as per our next hypothesis:

Hypothesis 5: Internationalized SMEs with stronger in-house technological capabilities achieve much superior intellectual resource growth over time as compared to their domestic market-focused counterparts.

Research on organizational routines indicates that alliance capability can be regarded as a distinct dynamic capability (Eisenhardt \& Martin, 2000; Helfat et al., 2007; Zollo \& Winter, 2002). In particular, alliance capabilities are reflected in the organizational routines which include coordination, learning, sensing, and transformation (Teece et al., 1997). Consistent with Helfat et al.'s (2007) concept of relational capability, alliance capabilities are essentially the abilities to shape and reconfigure firms' resource base by accessing the resources of its partners. Thus, through alliances, SMEs explore knowledge outside their organizational and national boundaries and their foreign alliance capabilities influence the degree to which internationalization contributes to intellectual resource growth. While Schilke and Goerzen (2010) suggest four components of alliance capabilities (i.e., coordination of activities and resources with alliance partners, sensing for the identification of alliance opportunities, transformation of alliances as they evolve, and learning through knowledge transfer across organizational boundaries), our discussion here is focused on learning routines as it is the most relevant component of alliance capability in our research context. 
The application of a firm's learning routine in the international arena likely results in the identification of a broad range of valuable resources and the effective absorption of those resources, contributing to the growth of intellectual resources for SMEs. Foreign partners can offer unique and nonredundant skills that spur innovation and creativity, especially when innovative knowledge is spatially concentrated (Fabrizio \& Thomas, 2012; Jaffe, Trajtenberg, \& Henderson, 1993) and embedded within specific national business systems (Gertler, 2001).

SMEs' international expansion also broadens the search territory for potential partners. By experiencing a broader range of alliance opportunities, internationalized SMEs build their alliance formation and post-formation management capabilities. Alliances with partners with distinctive value and culture systems can, therefore, enhance the knowledge and capability repertoire of internationalized SMEs (Jiang, Tao, \& Santoro, 2010; Lavie \& Miller, 2008) and this effect would be particularly strong in researchintensive industries. Yet, this is challenging to manage in the early stage of internationalization when SMEs are still grappling with diverse markets and trust building resulting from liability of outsidership and crossborder cognitive and normative barriers (Barkema et al., 1997; Lane \& Lubatkin, 1998; Verwaal, 2017). These arguments suggest that internationalized SMEs may or may not achieve stronger intellectual resource growth than their domestic market-focused counterparts in the short term but will likely do so with the passage of time. ${ }^{2}$ Thus, alliance capabilities are expected to catapult the intellectual resource growth in the process, as per our next hypothesis:

Hypothesis 6: Internationalized SMEs with stronger alliance capabilities achieve much superior intellectual resource growth over time as compared to their domestic market-focused counterparts.

\subsection{In-house technological and alliance capabilities: Differential impacts on resource growth}

Prior studies indicate that in-house technological and alliance capabilities are both important in enabling and facilitating firm growth, especially as it relates to innovation and knowledge generation

\footnotetext{
${ }^{2}$ It is theoretically difficult to specify whether internationalized SMEs will grow more (or less) than their domestic counterparts in the short run due to the liability of foreignness and liability of outsidership. Our main point here is that the former will grow more strongly than the latter as firm-specific capabilities and country-specific resources are combined to yield a greater sum of growth over time.
} 
(Cassiman \& Veugelers, 2006; Grigoriou \& Rothaermel, 2017). In-house technological capabilities tend to be embedded in the existing routines and are often leveraged for resource exploitation in accordance with internalization theory. In contrast, alliance capabilities often entail frequent adjustments and are largely geared toward resource exploration in line with the dynamic capabilities-based perspective (Teece, 2014; Weerawardena et al., 2007). In fact, in rapidly changing environments, there is a need for constant surveillance of markets and technologies and the willingness to adjust the firm's structure and operations (Teece et al., 1997).

Our theoretical argument is that external resources, especially those that are knowledge-based, are often more useful for a firm's new development than internal resources. Of course, the firm needs in-house technological capabilities to search for and absorb the relevant external resources and to facilitate coordination with external partners. For resource-constrained SMEs, however, the reliance on external collaboration is likely to be more important than the leverage of in-house technological capabilities (Love, Roper, \& Vahter, 2014). Partnering firms can offer SMEs access to knowledge and other resources to overcome the liability of smallness and liability of outsidership (Yu, Gilbert, \& Oviatt, 2011). There is also evidence that biopharmaceutical firms, for example, raise far more funding through alliances than through other channels including internal accumulation (Nicholson, Danzon, \& McCullough, 2005), particularly when SMEs expand abroad (Colombo, Grilli, Murtinu, Piscitello, \& Piva, 2009; Fernhaber, McDougallCovin, \& Shepherd, 2009) where alliances offer them not only opportunities and resources but also the much-needed legitimacy in new markets (Chen \& Huang, 2004).

Indeed, SMEs have to form alliances to compensate for their internal resource scarcity, especially in research-intensive industries where alliance capabilities play a vital role in mobilizing networks of knowledge, innovation, and technology (Partanen et al., 2008). It should be noted that, in the short term, SMEs' in-house technological capabilities may play a more critical role than alliance capabilities in facilitating the accumulation of financial and intellectual resources because the effect of the latter has yet to emerge due to the time needed to establish governance structures for and develop mutual trust in foreign partnerships (Li, Eden, Hitt, \& Ireland, 2008; Verwaal \& Donkers, 2002). In the long term, however, these 
alliance capabilities and the resulting diverse partner portfolios support the internationalized SMEs' coordination and transformation routines for future growth (Goerzen \& Beamish, 2005). Moreover, the enhanced alliance capabilities through international expansion can be transferred to home operations, contributing to intellectual resource growth of the SMEs back in their home country. Thus, we expect that alliance capabilities have a stronger long-term enabling effect on financial and intellectual resource growth than in-house technological capabilities for internationalized SMEs.

Hypothesis 7: Alliance capabilities play a more significant role in strengthening financial and intellectual resource growth than in-house technological capabilities for internationalized SMEs as compared to their domestic market-focused counterparts in the long run.

\section{Methodology}

\subsection{Empirical setting: SMEs in the U.S. biopharmaceutical industry 1987 - 2001}

We selected publicly listed U.S. biopharmaceutical SMEs to test our hypotheses for several reasons. First, the biopharmaceutical industry is characterized by large R\&D expenditures, long product development cycles, profound uncertainty, and complicated regulatory procedures in different countries (Choi \& Contractor, 2016; Pisano, 2006). Thus, in-house technological and alliance capabilities are critical for survival and growth in this industry. Second, the U.S. accounts for nearly half of global biopharmaceutical market (Mergent, 2003); for U.S. biopharmaceutical SMEs, therefore, domestic expansion is clearly a viable option for firm growth making the comparison of resource growth of internationalized versus domestic SMEs more meaningful. Third, our focus on endogenous firm growth, a single industry, and a single home country setting provides a good control for many exogenous effects. Fourth, our observation period from 1987 to 2001 matches well with two milestones in the U.S. biopharmaceutical industry: one was the passage of Hatch-Waxman Act in the mid-1980s which created the generic drug industry that threatened the large pharmaceutical firms and the other was the completion of Human Genome Project in 2001-2002 which made biotechnology more viable (Grabowski, 2011).

\subsection{Data collection}

We obtained our sample through several steps. First, a list of 112 single business U.S. biopharmaceutical firms was extracted from Compustat spanning from 1987 to 2001 . These single business 
firms had at least 95 percent of their sales from the biopharmaceutical segment from 1987 to 2001. Second, only firms that had existed for at least ten years during this observation period were selected as we wanted to compare the resource growth paths of internationalizing versus domestic firms. Third, we followed the standard definition of U.S. SME thereby dropping the firms with over 500 employees at the beginning of the growth trajectories that we examined, yielding a final sample of 870 firm-year observations of 70 SMEs.

We relied on multiple sources to collect data on the internationalization of our sample firms. In particular, we used the Lexis-Nexis Directory of Corporate Affiliations and the Directory of American Firms Operating in Foreign Countries to identify foreign subsidiaries. We also searched Securities Data Corporation Platinum to obtain the data on foreign alliances where we used the keyword "alliance" to refer to various interfirm relationships (White \& Lui, 2005). We retrieved firm financial data from the Compustat database and used company annual reports to corroborate the data. In addition, we collected patent data from the US Department of Commerce Patent and Trademark Office's Patent Bibliographic File.

\subsection{Dependent variables}

Financial resource growth. Tobin's $q$ was used because it measures the capitalized value of firm rents and reflects sustainable future cash flows (Hirschey \& Weygandt, 1985; Smirlock, Gilligan, \& Marshall, 1984). We followed Whited (2001) and used the market value of assets divided by the book value of assets. Specifically, we adopted the formula which Chung and Pruitt (1994) used because their analysis revealed that this approximation of Tobin's q had an extremely high predictive accuracy as compared to the original formulation of this variable. ${ }^{3}$

Intellectual resource growth. Since patents and citations reflect intellectual resources in the biopharmaceutical industry, we used two variables to capture intellectual resource growth: (1) new patent count and (2) new patent citations (both scaled by number of employees) (Fabrizio \& Thomas, 2012).

\subsection{Main independent variables}

\footnotetext{
${ }^{3}$ Chung and Pruitt's (1994) formula is Tobin's $q=($ MVE + PREFER + DEBT)/ASSETS where MVE is the market value of equity (common shares outstanding * the closing stock price); PREFER is the liquidating value of preferred stock; DEBT is the value of debt, and ASSETS is the total assets.
} 
In-house technological capabilities. We used $R \& D$ stock to measure in-house technological capabilities by calculating the total value of a firm's current year R\&D expenditure plus R\&D spending from the four previous years depreciated at fifteen percent because it captures the cumulative effect of a firm's technological development (Berry, 2006).

Alliance capabilities. We used the total number of alliances to proxy alliance capabilities following Rothaermel and Deeds (2006, p.433) who argued that a "tangible benefit of a firm's alliance management capability is that it enhances the firm's ability to manage effectively a large number of alliances, an observable consequence of an unobservable alliance capability."

International presence. A firm must have at least one foreign subsidiary or foreign alliance during our observation period to be classified as an internationalized firm. Thus, we included the dummy variable, international presence, to distinguish internationalized from domestic SMEs.

Temporal effect. This variable takes the integer value from 0 to 14 with 0 being 1987, the starting year, and 14 being 2001, the last year of our observation period. In addition to its direct impact, the temporal effect is incorporated to test the moderating effect of the passage of time as shown in Figure 1.

\subsection{Control variables}

Since our study examines the resource growth of the firm, there is a need to control the effects of other resources and capabilities such as physical resources, human resources, non-technological capabilities, intra-firm network on the growth of financial and intellectual resources (Brush, Greene, \& Hart, 2001; Li, Lin, \& Arya, 2008). ${ }^{4}$ Thus, we control for the following variables.

Physical resources. We used total assets from a firm's balance sheet to proxy physical resources, i.e., tangible resources.

\footnotetext{
${ }^{4} \mathrm{We}$ also included intellectual resource growth (i.e., new patent count lagged by one year) as a control variable when financial resource growth (i.e., Tobin's q) is the dependent variable and Tobin's q lagged by one year as a control variable when intellectual resource growth is the dependent variable.
} 
Human resources. Consistent with Lockett, Wiklund, Davidsson, and Girma (2011), we used number of employees to measure human resources. Given that the majority of biopharmaceutical employees are scientists or researchers, this measure is a reasonable proxy for human capital.

Non-technological capabilities. We used selling, general, and administrative stock (SGA stock) as a proxy for non-technological capabilities (De Carolis, 2003; Pitelis \& Verbeke, 2007) calculated as the firm's current year SGA expenditure, plus that of the previous two years depreciated at a fifty percent rate (Hirschey \& Weygandt, 1985).

Intra-firm network. We used total number of subsidiaries to measure intra-firm network as SME subsidiaries contribute to the entire firm's resource growth.

We also included several additional control variables including return on assets (ROA), as SME's profitability might affect its financial and intellectual resource growth, cash and cash equivalents scaled by total assets, as financial slack is associated with a firm's growth and performance (Penrose, 1995; Vanacker, Collewaert, \& Zahra, 2017), ${ }^{5}$ total sales and foreign to total sales ratio, representing degree of commercialization and foreign market dependence for SMEs, firm age measured by the number of years since the founding of a firm and year dummies for controlling yearly fixed effects. The summary of the variables and measures is attached as an appendix.

\subsection{Analytical model}

To test our hypotheses, we used Stata to conduct generalized least squared regressions. Given our time-series cross-sectional (i.e., panel) data, we controlled for heteroscedasticity and firm-specific autocorrelation. For the dependent variables, we used the three-year moving averages (i.e., $\left(\mathrm{Y}_{t}+\mathrm{Y}_{t-1}+\mathrm{Y}_{t}\right.$ 2)/3). For the major independent variables, namely $R \& D$ stock, total number of alliances and the main control variables such as total assets, number of employees, SGA stock, number of subsidiaries, we used the three-year moving averages lagged by one year (i.e., $\left.\left(\mathrm{X}_{t-1}+\mathrm{X}_{t-2}+\mathrm{X}_{t-3}\right) / 3\right)$. International presence,

\footnotetext{
${ }^{5}$ We acknowledge the valuable suggestion by an anonymous reviewer that financial slack should be controlled for.
} 
temporal effect, cash and cash equivalents/total assets, total sales, foreign to total sales ratio, firm age and year dummies are contemporaneous variables.

We followed the standard practice to generate three two-way and two three-way interaction terms including "international presence $\mathrm{x}$ temporal effect" (i.e., the internationalization effect over time), " $R \& D$ stock x international presence" (i.e., the moderating role of in-house technological capabilities for internationalizing firms), "total number of alliances $\mathrm{x}$ international presence" (i.e., the moderating role of alliance capabilities for internationalizing firms), " $R \& D$ stock $\mathrm{x}$ international presence $\mathrm{x}$ temporal effect" (i.e., the moderating role of in-house technological capabilities for internationalizing firms over time) and "total number of alliances $\mathrm{x}$ international presence $\mathrm{x}$ temporal effect" (i.e., the moderating role of alliance capabilities for internationalizing firms over time). In addition, we generated two additional two-way interaction terms (i.e., $R \& D$ stock x temporal effect, total number of alliances $\mathrm{x}$ temporal effect) as control variables as we could not rule out their possible effects on the growth of financial and intellectual resources.

\section{Results}

Table 1 displays the descriptive variable statistics for the domestic and internationalized groups, respectively. The mean values show that an average internationalized SME owns more new patents and patent citations than an average domestic SME. It is also clear that the internationalized group has more alliances and subsidiaries than the domestic group on average. A further breakdown indicates that internationalized SMEs have most of their foreign alliances in Americas (especially Canada and Mexico) and Europe (especially Germany, UK, and Switzerland) and have most of their foreign subsidiaries in Europe (especially the Netherlands, UK) and Asia Pacific (especially Japan).

$$
\text { *** Insert Table } 1 \text { about here } * * *
$$

Table 2 is the correlation matrix with pooled observations. Several pairwise correction coefficients are each relatively large $(>0.7)$ such as the ones between new patent count and new patent citations as well as between total sales and number of employees although this was not unexpected. The variance inflating factor test indicated that all scores for the variables displayed in Table 2 were less than 8 ; the condition index test showed that the largest is less than 20. Thus, multicollinearity was not a concern. 
*** Insert Table 2 about here***

Tables 3-5 show the results of the generalized least squared estimators with Tobin's q, new patent count (scaled by number of employees), and new patent citations (scaled by number of employees) as the dependent variables, respectively. In each of these tables, there are five regression models. The baseline model includes only control and independent variables (without interaction terms). Model 1 includes all the independent and control variables plus the two-way interaction term between international presence and temporal effect. Model 2 adds the interaction terms among $R \& D$ stock, international presence and temporal effect. Model 3 is different than Model 2 as it includes the interaction terms associated with total number of alliances instead of $R \& D$ stock. Model 4 shows the results with all the interaction terms included. It should be noted that for Model 4, the standard errors and the 95 percent confidence interval are reported by following the recent practices (Meyer, Witteloostuijn, \& Beugelsdijk, 2017; Verwaal, 2017).

*** Insert Tables 3, 4, and 5 about here***

In Table 3, where Tobin's $q$ is the dependent variable, the coefficient of international presence is positive and significant in the baseline model. However, after the interaction term between international presence and temporal effect is added, the main effect is no longer significant whereas the interaction term is positive and significant (see Model 1). Models 2-4 also show consistently the positive and significant interaction indicating that internationalized SMEs achieve stronger growth in financial resources than those following a domestic expansion strategy over time which supports Hypothesis 1 . Table 3 also shows that both $R \& D$ stock (a proxy for in-house technological capabilities) and total number of alliances (measuring alliance capabilities) are largely beneficial to all SMEs in terms of their main effects. When the interaction terms are included, $R \& D$ stock has a negative moderating impact on financial resource growth of internationalized SMEs initially $\left(\beta_{\mathrm{R} \& \mathrm{D} \text { stock }}\right.$ International presence $=-0.02, \mathrm{p}=0.02$ in Model 2$)$ and only starts to make a positive influence over time $\left(\beta_{R \& D \text { stock * International presence * Temporal effect }}=0.007, p=0.009\right.$ in Model 2$)$.

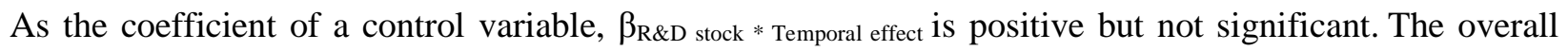
impact of total number of alliances on Tobin's $q$ is somewhat more complex given that $\beta_{\text {Total number of alliances * }}$ International presence $=-1.7(\mathrm{p}<0.01), \beta_{\text {Total number of alliances * Temporal effect }}=-0.3(\mathrm{p}<0.01)$, and $\beta_{\text {Total number of alliances * }}$ 
International presence * Temporal effect $=0.3(\mathrm{p}<0.01)$ in Model 3. Nevertheless, the pattern is similar in that there is a positive impact of total number of alliances on Tobin's q with the passage of time. A consistent set of results are displayed in Model 4 with all the interaction terms included.

Figure 2 illustrates the overall marginal effects of $R \& D$ stock (see the left graph) and total number of alliances (see the right graph) on Tobin's $q$ for internationalized and domestic SMEs over time. Based on Model 4, we can derive that the marginal effects of $R \& D$ stock on Tobin's $q$ for internationalized and domestic SMEs are approximately 0.006*temporal effect-0.007 and 0.019-0.00005*temporal effect respectively (see the left graph); the marginal effects of total number of alliances on Tobin's $q$ for internationalized and domestic SMEs are $0.03 *$ temporal effect +0.28 and $2-0.3 *$ temporal effect respectively (see the right graph). ${ }^{6}$ Thus, the marginal effects increase with temporal effect for internationalized SMEs but decrease for domestic SMEs. The results suggest that both in-house technological and alliance capabilities facilitate stronger financial resource growth of internationalizing SMEs than domestic SMEs over time. Assuming the temporal effect is 6 indicating the later years during our observation period, the change of $R \& D$ stock by one million US\$ would result in 0.029 unit change of Tobin's $q$ for internationalized SMEs and about 0.019 unit change of Tobin's $q$ for domestic SMEs. Similarly, one more alliance would result in 0.46 unit change of Tobin's $q$ for internationalized SMEs and 0.2 unit change of Tobin's $q$ for domestic SMEs. We note in Figure 2 that with 95 percent confidence interval being taken into account, the marginal effect of R\&D stock on Tobin's $q$ for internationalized SMEs becomes positive and significant surpassing the effect for domestic SMEs with the passage of time whereas the marginal effect of alliances on Tobin's $q$ turns positive over time for internationalized SMEs but is not significant within our observation period despite the upward trend. Thus, Hypothesis 2 is supported whereas there is only suggestive evidence to support Hypothesis 3. In other words, our findings show that internationalized SMEs with stronger in-house technological capabilities achieve much superior financial resource growth over

\footnotetext{
${ }^{6}$ The Stata program (with all the relevant syntax) used for the estimation and graphic illustration is available upon request.
} 
time as compared to their domestic market-focused counterparts whereas it is less conclusive when it comes to alliance capabilities.

$$
* * * \text { Insert Figure } 2 \text { about here } * * *
$$

In Table 4, where new patent count (scaled by number of employees) is the dependent variable, the coefficient of international presence is negative but mostly not significant whereas the interaction term between international presence and temporal effect is positive but largely insignificant. Table 5, where new patent citations (scaled by number of employees) is the dependent variable, shows mixed signs but none are significant. These results indicate that being international per se does not enable SMEs to accumulate intellectual resources better over time and, thus, Hypothesis 4 is not supported. Namely, there is a lack of evidence that internationalized SMEs achieve stronger intellectual resource growth than those following a domestic expansion strategy over time.

Both Tables 4 and 5 show that the main effect of $R \& D$ stock is positive and significant. When the interaction terms are included, the overall impact of $R \& D$ stock becomes complex. We note that with the exception of Model 2 in Table 4, the three-way interaction among $R \& D$ stock, international presence and temporal effect is negative and significant (see Model 4 in Table 4 as well as Models 2 and 4 in Table 5). This indicates the overall impact of $R \& D$ stock on new patent count and new patent citations for internationalized SMEs tends to turn negative with the passage of time. As for alliances, both Tables 4 and 5 indicate that the three-way interaction among total number of alliances, international presence, and temporal effect is positive and significant over time. ${ }^{7}$ Figures 3 and 4 illustrate the effects of $R \& D$ stock (i.e., left graph) and total number of alliances (i.e., right graph) on new patent count and new patent citations (both scaled by the number of employees) for internationalized and domestic SMEs over time. Overall, Hypothesis 5 is not supported but Hypothesis 6 is supported. That is, in-house technological capabilities do not facilitate stronger intellectual resource growth of internationalized SMEs as opposed to domestic SMEs

\footnotetext{
${ }^{7}$ Although the interaction terms involving alliances are not always statistically significant in Tables 4 and 5, the overall result is that the total number of alliances has a positive impact on new patent count and new patent citations (scaled by number of employees) for internationalized SMEs over time which is clearly displayed in Figures 3 and 4.
} 
over time but alliance capabilities do. Based on Model 4 in Table 4 for example, we can derive that the marginal effect of total number of alliances on new patent count for internationalized and domestic SMEs are approximately $1.1 *$ temporal effect +2.17 and $1.17-0.5 *$ temporal effect respectively (right graph in Figure 3). Assuming temporal effect is 6 indicating the later years during our observation period, one more alliance would result in 8.77 more new patents (per thousand employees) for internationalized SMEs and a reduction of 1.83 new patents (per thousand employees) for domestic SMEs.

$$
\text { *** Insert Figures } 3 \text { and } 4 \text { about here*** }
$$

To test Hypothesis 7, we generated the reduced forms representing the relationships between $R \& D$ stock and total number of alliances (as independent variables) and Tobin's q, new patent count (scaled by number of employees) and new patent citations (scaled by number of employees) as dependent variables. For example, we can produce the following reduced form based on Model 4 in Table 3. Tobin's $q=\left(\beta_{\mathrm{R} \& \mathrm{D}}\right.$ stock $+\beta_{\mathrm{R} \& \mathrm{D} \text { stock } * \text { International presence }}+\beta_{\mathrm{R} \& \mathrm{D} \text { stock } * \text { temporal effect }} *$ temporal effect $+\beta_{\mathrm{R} \& \mathrm{D} \text { stock } * \text { International presence * Temporal }}$ effect $*$ Temporal effect $) * R \& D$ Stock $+\left(\beta_{\text {Total number of alliances }}+\beta_{\text {Total number of alliances * International presence }}+\beta_{\text {Total number of }}\right.$ alliances * temporal effect $*$ Temporal effect $+\beta_{\text {total number of alliances } * \text { International presence * Temporal effect }} *$ Temporal effect $) *$ Total number of alliances $=(0.006 *$ Temporal effect -0.01$) * R \& D$ Stock $+(0.03 *$ Temporal effect +0.3$)$ * Total number of alliances. It is clear that the second coefficient (i.e., slope for alliances) is larger than the first coefficient (slope for $R \& D$ stock) given any value of Temporal effect. We calculated the standardized coefficients for both and find the results to be the same. We can draw the same (and indeed even stronger) conclusion when we examine Model 4 in Tables 4 and 5. Overall, our findings suggest that in researchintensive industries, alliance capabilities facilitate the intellectual resource growth and to a lesser extent the financial resource growth of internationalized SMEs more significantly than in-house technological capabilities in the long run, which supports Hypothesis 7.

We examined potential endogeneity related to model specification. ${ }^{8}$ Since one can argue that more resources lead to more resources regardless of internationalization, we adopted MANOVA analysis to

\footnotetext{
${ }^{8}$ Shaver (1998) demonstrated the need to account for self-selection bias in FDI survival analysis. Our study focuses on the two trajectories of firm growth and thus, self-selection bias does not apply in the same way.
} 
compare the two groups of SMEs in terms of Tobin's $q$ and new patent count in the initial 3-6 years of our observation period and we found no significant difference. We note that a one-year lagged new patent count (scaled by number of employees) is included in the models where Tobin's $q$ is the dependent variable and a one-year lagged Tobin's $q$ is incorporated in the models where new patent count and new patent citations (both scaled by number of employees) are dependent variables. There were no significant effects. Further, we examined whether the outliers could skew the outcomes. We dropped the highest one percent and the lowest one percent of the R\&D stock and did the same for alliances and found that the results were highly consistent.

\section{Discussion}

Notwithstanding the growing body of literature on SME internationalization, performance, and growth via resource exploitation and/or exploration, there is limited understanding of the dynamic resource accumulation of SMEs going international as opposed to those adhering to domestic expansion. We note that this gap in the literature may just as well indicate the necessity of integrating the dynamic capabilitiesbased perspective into the received IB theories (Cantwell, 2014). In this study, we draw upon the dynamic capabilities-based theory of MNE and treat internationalized SMEs as business entities orchestrating and leveraging differential and innovative capabilities across national borders as opposed to purely domestic firms (Cantwell, 2014; Teece, 2014). Through this theoretical lens, our findings enhance our understanding of what and how SMEs gain from going international thereby inferring why some SMEs choose to go international while others remain local (Cavusgil \& Knight, 2015; Zahra, 2005) and whether SMEs' international expansion is geared toward resource exploitation or exploration considering their joint liabilities of smallness, foreignness, and outsidership. In particular, the insights derived from our analysis are most relevant to SMEs based in a large and advanced home market where productive opportunities and resources tend to be abundant. Our study starts with the premise that the accumulation of essential resources is critical for the survival and growth of SMEs and international expansion is but one way to accrue such resources. In addition to the dynamic capabilities-based perspective, we extend Penrose's TGF to examine 
the financial and intellectual resource growth of internationalized and domestic SMEs in the U.S. biopharmaceutical industry over time.

\subsection{Financial resource growth through international expansion}

We argue that internationalized SMEs in research-intensive industries should achieve stronger growth of financial resources in the long term as compared to their domestic counterparts because SMEs are constrained in tangible resources and experiences and, therefore, face additional challenges in the international arena in the short run. Further, SMEs are particularly vulnerable to liabilities of foreignness and outsidership in the earlier years of internationalization. Our analysis confirms that internationalization enhances financial resource accumulation of U.S. biopharmaceutical SMEs only in the long run.

This finding suggests that SMEs in research-intensive industries pursue international expansion largely for resource exploration, thereby targeting long-term financial resource accumulation. From a different perspective, SME's international presence only draws a positive response from capital markets after a period of adaptation and experiment. The fact that the foreign to total sales has a negative impact on financial resource growth further confirms that the attractiveness of internationalization does not come from foreign product markets but likely from the resource accessibility (being available for exploration) in foreign research communities.

We also note that in-house technological capabilities (i.e., R\&D stock) and alliance capabilities are likely conducive to financial resource growth of internationalized SMEs over time. Although this is congruent with the classic argument regarding the challenges of operating abroad in the early stage of internationalization, it is important to point out that SMEs pursuing domestic expansion benefit from inhouse technological and alliances capabilities in a more significant way for an extended period of time suggesting they tend to focus on resource exploitation (see the stronger marginal effects on Tobin's q for domestic SMEs in earlier years in Figure 2). This may explain why some biopharmaceutical SMEs, especially among those based in large home countries such as the U.S., choose to adhere to domestic expansion strategies - or at least were not eager to go international. This represents an important 
contribution of this study as the literature on the multinationality-performance relationship has not captured this phenomenon as domestic expansion strategies are rarely analyzed.

\subsection{Intellectual resource growth through international expansion}

We expected that internationalized SMEs would accumulate intellectual resources more so than their domestic counterparts in the long run yet we have found that internationalization, per se, does not have such an influence over time nor do our findings provide support for the argument that in-house technological capabilities facilitate such intellectual resource growth in the international arena. Instead, we find that it is alliance capabilities that facilitate internationalized SMEs to accumulate intellectual resources more than their domestic counterparts over time.

Our results cannot be directly derived from the received MNE/IB theories including the updated internalization theory (Rugman \& Verbeke, 2003; Teece, 2014) and the knowledge-based evolutionary theory (Kogut \& Zander, 1993). In fact, that in-house technological capabilities (i.e., R\&D stock) were initially instrumental but later played a diminishing or even a negative role in the intellectual resource growth of internationalized SMEs is inconsistent with the tenet of transfer and exploitation of resources and capabilities or firm-specific advantages through international expansion (Lu \& Beamish, 2004; Rugman \& Verbeke, 2003).

We argue instead that alliance capabilities, embedded in learning and knowledge development routines (Kale, Dyer, \& Singh, 2002), reflect a firm's entrepreneurial capabilities for resource/knowledge exploration because the search for and management of a growing network of alliances is associated with substantial uncertainty and instability, especially in the international arena. This is consistent with the dynamic capabilities-based perspective of MNE (Teece, 2014) as well as Penrose's insight that entrepreneurial processes for exploration of new resources and capabilities are critical drivers for firm growth (Pitelis \& Verbeke, 2007), though Penrose paid only limited attention to firm alliances in the crossnational context (Lockett et al., 2011; Penrose, 1995). Building on TGF and the dynamic capabilities-based perspective of MNE, we contribute to the IB literature by showing that alliance capabilities are crucial in the long run (albeit less clear in the short term) for internationalized SMEs to enhance innovative outputs 
in such research-intensive industries as biopharmaceutical sector where uncertainty and complexity challenge even the largest global players (Madhok, 2002; Pisano, 2006). Our result here also appears to be in line with Fransson, Håkanson, and Liesch's (2011) argument that knowledge development can take place efficiently through broadly defined non-hierarchical structures-“epistemic communities" even in the diverse cross-national environments.

\subsection{Go international or remain domestic?}

Having discussed our main results, we return to reflect on the key issue of why some SMEs choose to go international while some others do not. Penrose, among other scholars, stresses the path dependence nature of firm growth. Path dependence results from the existence of long-term mobility and imitation barriers (Lee, Lee, \& Rho, 2002). Our study suggests that the bifurcated growth trajectories of SMEs (i.e., international versus domestic) are path dependent in part due to their alliance capabilities which is consistent with Oehme and Bort (2015) as well as Dimitratos, Johnson, Plakoyiannaki, and Young (2016) who have demonstrated that an SME's external connections and embeddedness were influential in SME internationalization. SMEs with stronger alliance capabilities may be better positioned to pursue international expansion as exemplified in our investigation of the U.S. biopharmaceutical industry. In fact, we find that internationalized SMEs tend to have far more alliances than their domestic counterparts prior to international expansion (this result is not reported here to conserve space). It is reasonable to presume that SMEs experienced with domestic alliances may have developed the operational routines to cope with uncertainty (i.e., a particular dynamic capability) and, thus, are more likely to tap into the less familiar international arena. Once on the international growth path, these SMEs tend to show stronger growth of the essential resources over time such as financial and intellectual resources.

For some extended period of time, domestic SMEs may outperform their internationalized counterparts in terms of leveraging in-house technological and alliance capabilities for the growth of financial resources because they are operating in the familiar home environment and tend to focus on resource exploitation (see Figure 2). However, it appears to be challenging for them to achieve superior long-term accumulation of financial resources as opposed to internationalized SMEs. Further, domestic 
SMEs are clearly at a disadvantage in growing intellectual resources over time which are strongly driven by firm alliances or more broadly epistemic communities in the international arena (see Figures 3 and 4). It should be noted that international alliance capabilities are difficult to imitate due to the uncertainty, potential risks, and unique historical conditions for alliance management. To refine and advance Teece's (2014, p.26) point that "asset augmentation [coming] fundamentally from R\&D and learning processes", our study indicates that "collaboration with a panoply of partners" for internationalized SMEs in researchintensive industries is more important than in-house technological capabilities in long-term intellectual resource accumulation. In line with the knowledge evolution perspective proposed by Zollo and Winter (2002), we may also make the inference that SMEs with strong (dynamic) alliance capabilities may be motivated to explore novel knowledge with partners in the international arena and is willing to spend time articulating and codifying the new knowledge for long-term success.

The phenomenon of path dependency is in part explained by Penrose (1995, p.35) who argued that "the most effective restriction on the quality of entrepreneurial services is that which stems from a lack of interest in experimenting with new and alien lines of activity, or in moving into new geographic areas." Our study makes a further contribution by showing the roles of two types of services as indicated by inhouse technological capabilities and alliance capabilities in firm growth. For SMEs relying upon or endowed with strong alliance capabilities, the path of international expansion may be effectively pursued (Dimitratos et al., 2016).

\subsection{Scholarly implications}

Our analyses and discussion bear important theoretical implications. First, our study suggests that research on the broadly defined relationship between multinationality and performance should address path dependence of resource accumulation which is likely playing a mediating role in driving both international expansion and performance rather than a moderating role between internationalization and performance which is so prevalent in the literature (Hilmersson \& Johanson, 2016; Li, 2007; Lu \& Beamish, 2004; Morck \& Yeung, 1991). Under the circumstances where the intrinsic value of multinationality needs to be examined, domestic firms should not be left out of the analysis. Second, that international expansion of 
SMEs in research-intensive industries results in more effective accumulation of financial and intellectual resources over time and alliance capabilities facilitate that process (especially intellectual resource growth) implies that resource exploration may motivate SMEs' internationalization more than exploitation. Although our findings were based on the investigation of the biopharmaceutical industry, the implications may extend beyond our industry context. Some recent research, for example, shows that the preponderance of alliances in facilitating intellectual resources may be widely observed (Kavusan, Noorderhaven, \& Duysters, 2016) and applies to other research-intensive industries such as the semiconductor industry (Hsu \& Ziedonis, 2013).

\subsection{Managerial relevance}

For SME managers, our study points to the importance of their dynamic capabilities to visualize long-term firm growth trajectories and resource accumulation and making choices (e.g., international expansion or not; resource exploitation or exploration) under uncertainty and based on their unique historical conditions (Helfat \& Raubitschek, 2000). For policymakers, there is a need to conceive and design differential catalysts for the long-term growth of SMEs. Prior research shows the conventional measures for promoting SME growth and innovation such as mentoring and human resource development as well as access to finance (Love \& Roper, 2015). Our findings suggest that policymakers need to build a repertoire to enable and assist SMEs for long-term resource growth in light of cultivating technological and alliance capabilities. In particular, policymakers need to attach great importance to business environment creation and program building that may consistently foster formation and management of domestic and international alliances for SMEs.

It should be noted that the practical implications of this study are probably as strong in the new millennium as in the stage between the historical enactment of the Henry-Waxman Act and the completion of the Human Genome Project which our data directly reflect. As a recent McKinsey report indicates: "This complexity and diversity [in the global biopharmaceutical industry] mean...companies in the sector are making difficult strategic choices about the product categories and parts of the value chain in which they want to participate. Access to key technologies and capabilities is also driving make-or-buy decisions, with 
many companies choosing to outsource activities - not because they don't want to do them, but because they can't." (Otto, Santagostino, \& Schrader, 2014)

\subsection{Limitations and suggestions for future research}

Since our study focuses on publically listed SMEs from the U.S. biopharmaceutical industry, there is clearly limitation of external validity. Thus, more industry-specific research on SME internationalization is warranted to see whether corroborating evidence can be attained in other industries as well as in countries outside the U.S. Regarding the latter, it would be particularly interesting to see if the results would be similar in the medium-sized countries whose domestic markets are still important in contrast to small and open market economies. Moreover, it is an open question as to whether our findings would be replicated in the case of private SMEs because they tend to face more challenges in international expansion due to their lack of visibility and legitimacy (being not publically traded). We also note that our sample includes all firms that survived and operated for a sustained period of time. Thus, there seems to be a "survival bias" as SMEs that were publically delisted within only a few years were not included in our analyses. While we acknowledge the likely impact on our estimation of the exclusion of these SMEs, the focus on the SMEs surviving the observation period is theoretically necessary and empirically pragmatic. Theoretically, since our focus was to compare resource accumulation of international expansion with that of domestic expansion over time, it is important to display the long-term growth trajectories of the two expansion paths. In this sense, the inclusion of the firms that failed or existed for only a short period of time would risk confounding the results. This is consistent with some prior literature such as Vermeulen and Barkema (2002). We would like to emphasize that our findings may be interpreted as being mainly applicable in the context where the long-term development of the firms could be observed. Empirically, if we presume that internationalized SMEs were more vulnerable than domestic SMEs due to liabilities of foreignness and outsidership, the implication is that our findings might be biased in favor of internationalized SMEs. We speculate that we might need to observe for a longer period of time to obtain the same or similar findings if we had included non-surviving firms in the sample. While we would like to emphasize that "survival bias" as described here does not compromise our contributions considering the nature of our study, we believe that it will be 
valuable to examine the differences in resource accumulation between surviving and non-surviving firms in the future.

\section{Conclusion}

Our study seeks to examine what and how SMEs gain in terms of essential resource accumulation through international expansion as opposed to domestic expansion over time. We find that in a researchintensive industry in a large and advanced domestic market, internationalized SMEs do enjoy some intrinsic value of multinationality in financial resource accumulation in the long run but they do not accrue more financial resources than their domestic counterparts in the short to medium run through leveraging in-house technological capabilities and alliance capabilities. In addition, internationalized SMEs are found to be able to accumulate their intellectual resources more strongly than their domestic counterparts over time only when they have strong alliance capabilities. Furthermore, we demonstrate that alliance capabilities are more salient than in-house technological capabilities in facilitating long-term accumulation of intellectual resources and financial resources (to a lesser extent) for internationalized SMEs. These empirical findings enrich and extend Penrose's insights of firm growth and contribute to our understanding of the specific roles of dynamic capabilities in SME internationalization and innovation. Finally, we note that our results infer that SMEs in resource-intensive industries gain the benefits of resource exploration via international expansion in the long run. To some extent, this inference provides some new insight as to why some firms go international and some others remain in their domestic markets (Cavusgil \& Knight, 2015; Zahra, 2005).

\section{Acknowledgements}

We would like to acknowledge the insightful comments from two anonymous reviewers and the constructive editorial advice from Martina Musteen. The first author thanks Dick Rylander for sharing his rich industrial experiences in the early stage of this research project. Wendy Ye, Wenjun Tu and Kailun Chen have provided able research assistance. 


\section{References}

Barkema, H. G., Bell, J. H., \& Pennings, J. M. (1996). Foreign entry, cultural barriers, and learning. Strategic Management Journal, 17(2): 151-166.

Barkema, H. G., Shenkar, O., Vermeulen, F., \& Bell, J. H. (1997). Working abroad, working with others: How firms learn to operate international joint ventures. Academy of Management Journal, 40(2): 426-442.

Berry, H. (2006). Shareholder valuation of foreign investment and expansion. Strategic Management Journal, 27(12): 1123-1140.

Brush, C. G., Greene, P. G., \& Hart, M. M. (2001). From initial idea to unique advantage: The entrepreneurial challenge of constructing a resource base. Academy of Management Executive, 15(1): 64-78.

Buckley, P. J., \& Casson, M. (2007). Edith Penrose's Theory of the Growth of the Firm and the strategic management of multinational enterprises. Management International Review, 47(2): 151-173.

Cantwell, J. (2014). Revisiting international business theory: A capabilities-based theory of the MNE. Journal of International Business Studies, 45(1): 1-7.

Cassiman, B., \& Veugelers, R. (2006). In search of complementarity in innovation strategy: Internal R\&D and external knowledge acquisition. Management Science, 52(1): 68-82.

Cavusgil, S. T., \& Knight, G. (2015). The born global firm: An entrepreneurial and capabilities perspective on early and rapid internationalization. Journal of International Business Studies, 46(1): 3-16.

Cerrato, D., Crosato, L., \& Depperu, D. (2016). Archetypes of SME internationalization: A configurational approach. International Business Review, 25(1): 286-295.

Chen, H. L., \& Huang, Y. (2004). The establishment of global marketing strategic alliances by small and medium enterprises. Small Business Economics, 22(5): 365-377.

Chetty, S., Johanson, M., \& Martín, O. M. (2014). Speed of internationalization: Conceptualization, measurement and validation. Journal of World Business, 49(4): 633-650.

Choi, J., \& Contractor, F. J. (2016). Choosing an appropriate alliance governance mode: The role of institutional, cultural and geographical distance in international research \& development (R\&D) collaborations. Journal of International Business Studies, 47(2): 210-232.

Chung, K. H., \& Pruitt, S. W. (1994). A simple approximation of Tobin's q. Financial Management, 23(3): 70-74.

Colombo, M. G., Grilli, L., Murtinu, S., Piscitello, L., \& Piva, E. (2009). Effects of international R\&D alliances on performance of high-tech start-ups: a longitudinal analysis. Strategic Entrepreneurship Journal, 3(4): 346-368.

De Carolis, D. M. (2003). Competencies and imitability in the pharmaceutical industry: An analysis of their relationship with firm performance. Journal of Management, 29(1): 27-50.

Dhanaraj, C., \& Beamish, P. W. (2003). A resource-based approach to the study of export performance. Journal of Small Business Management, 41(3): 242-261.

Dhanaraj, C., Lyles, M. A., Steensma, H. K., \& Tihanyi, L. (2004). Managing tacit and explicit knowledge transfer in IJVs: the role of relational embeddedness and the impact on performance. Journal of International Business Studies, 35(5): 428-442.

Di Gregorio, D., Musteen, M., \& Thomas, D. E. (2008). International new ventures: The cross-border nexus of individuals and opportunities. Journal of World Business, 43(2): 186-196.

Dimitratos, P., Johnson, J. E., Plakoyiannaki, E., \& Young, S. (2016). SME internationalization: How does the opportunity-based international entrepreneurial culture matter? International Business Review, 25(6): 1211-1222.

Eisenhardt, K. M., \& Martin, J. A. (2000). Dynamic capabilities: what are they? Strategic Management Journal, 21:1105-1121. 
Eisenhardt, K. M., \& Schoonhoven, C. B. (1996). Resource-based view of strategic alliance formation: Strategic and social effects in entrepreneurial firms. Organization Science, 7(2): 136-150.

Eriksson, K., Fjeldstad, Ø., \& Jonsson, S. (2017). Transaction services and SME internationalization: The effect of home and host country bank relationships on international investment and growth. International Business Review, 26(1): 130-144.

Fabrizio, K. R., \& Thomas, L. G. (2012). The Impact of local demand on innovation in a global industry. Strategic Management Journal, 33(1): 42-64.

Fernhaber, S. A., McDougall-Covin, P. P., \& Shepherd, D. A. (2009). International entrepreneurship: leveraging internal and external knowledge sources. Strategic Entrepreneurship Journal, 3(4): 297-320.

Fransson, A., Håkanson, L., \& Liesch, P. W. (2011). The underdetermined knowledge-based theory of the MNC. Journal of International Business Studies, 42(3): 427-435.

Gertler, M. S. (2001). Best practice? Geography, learning and the institutional limits to strong convergence. Journal of Economic Geography, 1(1): 5-26.

Goerzen, A., \& Beamish, P. W. (2005). The effect of alliance network diversity on multinational enterprise performance. Strategic Management Journal, 26(4): 333-354.

Grabowski, H. (2011). The evolution of the pharmaceutical industry over the past 50 years: a personal reflection. International Journal of the Economics of Business, 18(2): 161-176.

Grigoriou, K., \& Rothaermel, F. T. (2017). Organizing for knowledge generation: internal knowledge networks and the contingent effect of external knowledge sourcing. Strategic Management Journal, 38(2): 395-414.

Heimeriks, K. H., \& Duysters, G. (2007). Alliance capability as a mediator between experience and alliance performance: An empirical investigation into the alliance capability development process. Journal of Management Studies, 44(1): 25-49.

Helfat, C. E., Finkelstein, S., Mitchell, W., Peteraf, M., Singh, H., Teece, D., \& Winter, S. G. (2007). Dynamic capabilities: Understanding strategic change in organizations. Malden, MA: Blackwell Publishing

Helfat, C. E., \& Raubitschek, R. S. (2000). Product sequencing: co-evolution of knowledge, capabilities and products. Strategic Management Journal, 21: 961-979.

Hessels, J., \& Parker, S. C. (2013). Constraints, internationalization and growth: A cross-country analysis of European SMEs. Journal of World Business, 48(1): 137-148.

Hilmersson, M., \& Johanson, M. (2016). Speed of SME internationalization and performance. Management International Review, 56(1): 67-94.

Hirschey, M., \& Weygandt, J. J. (1985). Amortization policy for advertising and research and development expenditures. Journal of Accounting Research, 23(1): 326-335.

Hsu, D. H., \& Ziedonis, R. H. (2013). Resources as dual sources of advantage: Implications for valuing entrepreneurial firm patents. Strategic management journal, 34(7): 761-781.

Jaffe, A. B., Trajtenberg, M., \& Henderson, R. (1993). Geographic localization of knowledge spillovers as evidenced by patent citations. Quarterly Journal of Economics, 108(3): 577-598.

Jiang, R. J., Beamish, P. W., \& Makino, S. (2014). Time compression diseconomies in foreign expansion. Journal of World Business, 49(1): 114-121.

Jiang, R. J., Tao, Q. T., \& Santoro, M. D. (2010). Alliance portfolio diversity and firm performance. Strategic management journal, 31(10): 1136-1144.

Johanson, J., \& Vahlne, J. E. (2009). The Uppsala internationalization process model revisited: From liability of foreignness to liability of outsidership. Journal of International Business Studies, 40(9): 1411-1431.

Kale, P., Dyer, J. H., \& Singh, H. (2002). Alliance capability, stock market response, and long - term alliance success: the role of the alliance function. Strategic Management Journal, 23(8): 747-767.

Kale, P., \& Singh, H. (2007). Building firm capabilities through learning: the role of the alliance learning process in alliance capability and firm-level alliance success. Strategic Management Journal, 28(10): 981-1000. 
Kavusan, K., Noorderhaven, N. G., \& Duysters, G. M. (2016). Knowledge acquisition and complementary specialization in alliances: The impact of technological overlap and alliance experience. Research Policy, 45(10): 2153-2165.

Kirca, A. H., Hult, G. T. M., Roth, K., Cavusgil, S. T., Perryy, M. Z., Akdeniz, M. B., Deligonul, S. Z., Mena, J. A., Pollitte, W. A., Hoppner, J. J., Miller, J. C., \& White, R. C. (2011). Firm-specific assets, multinationality, and financial performance: A meta-analytic review and theoretical integration. Academy of Management Journal, 54(1): 47-72.

Knight, G. A., \& Cavusgil, S. T. (2004). Innovation, organizational capabilities, and the born-global firm. Journal of International Business Studies, 35(2): 124-141.

Kogut, B., \& Zander, U. (1993). Knowledge of the firm and the evolutionary theory of the multinational corporation. Journal of International Business Studies, 24(4): 625-645.

Kuivalainen, O., Sundqvist, S., \& Servais, P. (2007). Firms' degree of born-globalness, international entrepreneurial orientation and export performance. Journal of World Business, 42(3): 253-267.

Lampel, J., \& Bhalla, A. (2011). Living with offshoring: The impact of offshoring on the evolution of organizational configurations. Journal of World Business, 46(3): 346-358.

Lane, P. J., \& Lubatkin, M. (1998). Relative absorptive capacity and interorganizational learning. Strategic Management Journal, 19(5): 461-477.

Lavie, D., \& Miller, S. R. (2008). Alliance portfolio internationalization and firm performance. Organization Science, 19(4): 623-646.

Lee, J., Lee, K., \& Rho, S. (2002). An evolutionary perspective on strategic group emergence: a genetic algorithm-based model. Strategic Management Journal, 23(8): 727-746.

Li, D., Eden, L., Hitt, M. A., \& Ireland, R. D. (2008). Friends, acquaintances, or strangers? Partner selection in R\&D alliances. Academy of Management Journal, 51(2): 315-334.

Li, L. (2007). Multinationality and performance: A synthetic review and research agenda. International Journal of Management Reviews, 9(2): 117-139.

Li, L., Li, D., \& Dalgic, T. (2004). Internationalization process of small and medium-sized enterprises: Toward a hybrid model of experiential learning and planning. Management International Review, 44(1): 93-116.

Li, L., Lin, Z., \& Arya, B. (2008). The turtle-hare race story revisited: Social capital and resource accumulation for firms from emerging economies. Asia Pacific Journal of Management, 25(2): 251-275.

Lockett, A., Wiklund, J., Davidsson, P., \& Girma, S. (2011). Organic and Acquisitive Growth: Reexamining, Testing and Extending Penrose's Growth Theory. Journal of Management Studies, 48(1): $48-74$.

Love, J. H., \& Roper, S. (2015). SME innovation, exporting and growth: A review of existing evidence. International Small Business Journal, 33(1): 28-48.

Love, J. H., Roper, S., \& Vahter, P. (2014). Dynamic complementarities in innovation strategies. Research Policy, 43(10): 1774-1784.

Lu, J. W., \& Beamish, P. W. (2001). The internationalization and performance of SMEs. Strategic Management Journal, 22(6/7): 565-586.

Lu, J. W., \& Beamish, P. W. (2004). International diversification and firm performance: The S-curve hypothesis. Academy of Management Journal, 47(4): 598-609.

Madhok, A. (2002). Reassessing the fundamentals and beyond: Ronald Coase, the transaction cost and resource-based theories of the firm and the institutional structure of production. Strategic Management Journal, 23(6): 535-550.

Mangematin, V., Lemarie, S., Boissin, J-P., Catherine, D., Corolleur, F., Coronini, R., \& Trommetter, M. (2003). Development of SMEs and heterogeneity of trajectories: The case of biotechnology in France.

Research Policy, 32(4): 621-638.

McDougall, P. P., \& Oviatt, B. M. (2000). International entrepreneurship: the intersection of two research paths. Academy of Management Journal, 43(5): 902-908.

Mergent, I. (2003). The North America Pharmaceuticals Sectors: A Company and Industry Analysis. 
Meyer, K. E., Witteloostuijn, A. V., \& Beugelsdijk, S. (2017). What's in a p? Reassessing best practices for conducting and reporting hypothesis-testing research. Journal of International Business Studies, 48(5): 535-551.

Morck, R., \& Yeung, B. (1991). Why investors value multinationality. Journal of Business, 64(2): 165187.

Mowery, D. C., Oxley, J. E., \& Silverman, B. S. (1996). Strategic alliances and interfirm knowledge transfer. Strategic Management Journal, 17(S2): 77-91.

Nicholson, S., Danzon, P. M., \& McCullough, J. (2005). Biotech-pharmaceutical alliances as a signal of asset and firm quality. Journal of Business, 78(4): 1433-1464.

Oehme, M., \& Bort, S. (2015). SME internationalization modes in the German biotechnology industry: The influence of imitation, network position, and international experience. Journal of International Business Studies, 46(6): 629-655.

Oliver, A. L. (2001). Strategic alliances and the learning life-cycle of biotechnology firms. Organization Studies, 22(3): 467-489.

Otto, R., Santagostino, A., \& Schrader, U. (2014). From Science to Operations: Questions, choices, strategies for successes in Biopharma. McKinsey \& Company.

Partanen, J., Moller, K., Westerlund, M., Rajala, R., \& Rajala, A. (2008). Social capital in the growth of science-and-technology-based SMEs. Industrial Marketing Management, 37(5): 513-522.

Penrose, E. T. (1959). The Theory of the Growth of the Firm. Oxford: Oxford university press.

Penrose, E. T. (1995). The Theory of the Growth of the Firm ( $3^{\text {rd }}$ ed.). Oxford: Oxford university press.

Pisano, G. P. (2006). Can science be a business? Lessons from biotech. Harvard Business Review, 84(10): 114.

Pitelis, C., \& Verbeke, A. (2007). Edith Penrose and the future of the multinational enterprise: New research directions. Management International Review, 47(2): 139-149.

Pitelis, C. (2002). The growth of the firm: The legacy of Edith Penrose. Oxford: Oxford University Press.

Rothaermel, F. T., \& Deeds, D. L. (2006). Alliance type, alliance experience and alliance management capability in high-technology ventures. Journal of Business Venturing, 21(4): 429-460.

Rugman, A. M., \& Verbeke, A. (2002). Edith Penrose's contribution to the resource-based view of strategic management. Strategic Management Journal, 23(8): 769-780.

Rugman, A. M., \& Verbeke, A. (2003). Extending the theory of the multinational enterprise: internalization and strategic management perspectives. Journal of International Business Studies, 34(2): 125-137.

Schilke, O., \& Goerzen, A. (2010). Alliance management capability: An investigation of the construct and its measurement. Journal of Management, 36(5): 1192-1219.

Schreiner, M., Kale, P., \& Corsten, D. (2009). What really is alliance management capability and how does it impact alliance outcomes and success? Strategic Management Journal, 30(13): 13951419.

Shaver, J. M. (1998). Accounting for endogeneity when assessing strategy performance: does entry mode choice affect. Management Science, 44:571- 585.

Shi, W., \& Prescott, J. E. (2012). The effect of rhythm and entrainment of acquisition and alliance behaviors on firm performance: A temporal perspective. Organization Studies, 33(10): 1281-1310.

Shi, W., Sun, J., \& Prescott, J. E. (2012). A temporal perspective of merger and acquisition and strategic alliance initiatives: review and future direction. Journal of Management, 38(1): 164-209.

Simonin, B. L. (2004). An empirical investigation of the process of knowledge transfer in international strategic alliances. Journal of International Business Studies, 35(5): 407-427.

Smirlock, M., Gilligan, T., \& Marshall, W. (1984). Tobin's q and the structure-performance relationship. American Economic Review, 74(5): 1051-1060.

Sui, S., \& Baum, M. (2014). Internationalization strategy, firm resources and the survival of SMEs in the export market. Journal of International Business Studies, 45(7): 821-841.

Teece, D. J. (2014). A dynamic capabilities-based entrepreneurial theory of the multinational enterprise. Journal of International Business Studies, 45(1): 8-37. 
Teece, D. J., Pisano, G., \& Shuen, A. (1997). Dynamic capabilities and strategic management. Strategic Management Journal, 18(7): 509-533.

Vanacker, T., Collewaert, V., \& Zahra, S. A. (2017). Slack resources, firm performance, and the institutional context: Evidence from privately held European firms. Strategic Management Journal, 38(6): 1305-1326.

Verbeke, A., \& Forootan, M. Z. (2012). How Good are Multinationality-Performance (M-P) Empirical Studies? Global Strategy Journal, 2(4): 332 - 344.

Verbeke, A., Li, L., \& Goerzen, A. (2009). Toward more effective research on the multinationalityperformance relationship. Management International Review, 49(2): 149-161.

Vermeulen, F., \& Barkema, H. (2002). Pace, rhythm, and scope: process dependence in building a profitable multinational corporation. Strategic Management Journal, 23(7): 637-653.

Verwaal, E. (2017). Global outsourcing, explorative innovation and firm financial performance: A knowledge-exchange based perspective. Journal of World Business, 52(1): 17-27.

Verwaal, E., \& Donkers, B. (2002). Firm size and export intensity: Solving an empirical puzzle. Journal of International Business Studies, 33(3): 603-613.

Weerawardena, J., Mort, G. S., Liesch, P. W., \& Knight, G. (2007). Conceptualizing accelerated internationalization in the born global firm: a dynamic capabilities perspective. Journal of World Business, 42(3): 294-306.

Weigelt, C., \& Sarkar, M. B. (2012). Performance implications of outsourcing for technological innovations: managing the efficiency and adaptability trade-off. Strategic Management Journal, 33(2): 189-216.

White, S., \& Lui, S. Y. (2005). Distinguishing costs of cooperation and control in alliances. Strategic Management Journal, 26(10): 913-932.

Whited, T. M. (2001). Is it inefficient investment that causes the diversification discount? Journal of Finance, 56(5): 1667-1691.

Yu, J., Gilbert, B. A., \& Oviatt, B. M. (2011). Effects of alliances, time, and network cohesion on the initiation of foreign sales by new ventures. Strategic Management Journal, 32(4): 424-446.

Zahra, S. A. (2005). A theory of international new ventures: a decade of research. Journal of International Business Studies, 36(1): 20-28.

Zahra, S. A., Ireland, R. D., \& Hitt, M. A. (2000). International expansion by new venture firms: International diversity, mode of market entry, technological learning, and performance. Academy of Management Journal, 43(5): 925-950.

Zhou, L., Barnes, B. R., \& Lu, Y. (2010). Entrepreneurial proclivity, capability upgrading and performance advantage of newness among international new ventures. Journal of International Business Studies, 41(5): 882-905.

Zhou, L., \& Wu, A. (2014). Earliness of internationalization and performance outcomes: exploring the moderating effects of venture age and international commitment. Journal of World Business, 49(1): 132-142.

Zollo, M., \& Winter, S. G. (2002). Deliberate learning and the evolution of dynamic capabilities. Organization Science, 13(3): 339-351. 
Table 1.

Descriptive statistics of variables

\begin{tabular}{|c|c|c|c|c|c|c|c|c|}
\hline & \multicolumn{4}{|c|}{ Domestic (33 firms; $\mathrm{N}=476$ ) } & \multicolumn{4}{|c|}{ International (37 firms; $\mathrm{N}=395$ ) } \\
\hline & Mean & Std. Dev. & Min & $\operatorname{Max}$ & Mean & Std. Dev. & Min & $\operatorname{Max}$ \\
\hline Tobin's q & 3.89 & 8.32 & 0 & 61.12 & 4.10 & 3.86 & 0.14 & 29.85 \\
\hline New patent count & 1.33 & 3.25 & 0 & 24 & 2.24 & 9.44 & 0 & 112 \\
\hline New patent citations & 24.59 & 67.10 & 0 & 653 & 68.26 & 230.12 & 0 & 2509 \\
\hline R\&D stock (US\$ mn) & 24.15 & 40.85 & 0 & 376.77 & 26.90 & 35.36 & 0.33 & 263.81 \\
\hline Total number of alliances* & 0.41 & 1.26 & 0 & 9 & 3.33 & 4.33 & 0 & 28 \\
\hline Americas (Canada, Mexico etc.) & N/A & N/A & N/A & N/A & 1.5 & 3.87 & 0 & 15 \\
\hline Europe/Mideast/Africa (Germany, UK, Switzerland etc) & N/A & N/A & N/A & N/A & 0.78 & 1.38 & 0 & 9 \\
\hline Asia-Pacific (Japan, Greater China, India etc.) & N/A & N/A & N/A & N/A & 0.22 & 0.66 & 0 & 3 \\
\hline International presence & 0 & 0 & 0 & 0 & 1 & 0 & 1 & 1 \\
\hline Temporal effect & 7.58 & 4.05 & 1 & 14 & 7.44 & 4.08 & 1 & 14 \\
\hline Total assets (US\$ mn) & 35.79 & 59.68 & 0.04 & 474.20 & 47.16 & 100.03 & 0.40 & 793.72 \\
\hline Number of employees $(000)$ & 0.11 & 0.12 & 0.01 & 0.56 & 0.13 & 0.17 & 0.01 & 1.85 \\
\hline SGA stock (US\$ mn) & 16.80 & 21.76 & 0.26 & 121.95 & 19.89 & 50.61 & 0.14 & 466.17 \\
\hline Total number of subsidiaries* & 0.17 & 0.70 & 0 & 7 & 1.35 & 2.91 & 0 & 21 \\
\hline Americas (Mexico, Canada etc.) & N/A & N/A & N/A & N/A & 0.66 & 0.48 & 0 & 1 \\
\hline Europe/Mideast/Africa (The Netherlands, UK, Italy etc.) & N/A & N/A & N/A & N/A & 2.67 & 3.50 & 0 & 20 \\
\hline Asia-Pacific (Japan, Malaysia, South Korea etc.) & N/A & N/A & N/A & N/A & 1.31 & 1.28 & 0 & 10 \\
\hline Return on assets (ROA) & -0.65 & 2.98 & -57 & 13.18 & -0.43 & 0.59 & -3.56 & 0.64 \\
\hline Cash and cash equivalents/Total assets $\dagger$ & 0.43 & 0.33 & 0 & 1.41 & 0.51 & 0.28 & 0.002 & 0.99 \\
\hline Total sales (US\$ mn) $\ddagger$ & 15.37 & 25.78 & 0 & 114.86 & 18.50 & 43.03 & 0 & 369.83 \\
\hline Foreign to total sales ratio & 0.07 & 0.18 & 0 & 1 & 0.09 & 0.17 & 0 & 1 \\
\hline Firm age & 16.00 & 12.86 & 1 & 67 & 13.14 & 7.24 & 1 & 41 \\
\hline
\end{tabular}

Note: *a small number of foreign alliances and subsidiaries are not included in the triad regions because their locations were not precisely described.

$\dagger \mathrm{N}=442$ for domestic firms and 363 for internationalized firms; $\$$ Total sales were reported as negligible in a few cases.

The order of the variables is aligned with the description under "Methodology". 
Table 2.

Correlation matrix

\begin{tabular}{|c|c|c|c|c|c|c|c|c|c|c|c|c|c|c|c|c|c|c|c|}
\hline & Variables & Mean & SD & 1 & 2 & 3 & 4 & 5 & 6 & 7 & 8 & 9 & 10 & 11 & 12 & 13 & 14 & 15 & 16 \\
\hline 1 & Tobin's q & 3.96 & 5.72 & 1 & & & & & & & & & & & & & & & \\
\hline 2 & New patent count & 17.04 & 35.22 & 0.02 & 1 & & & & & & & & & & & & & & \\
\hline 3 & New patent citations & 480.37 & 1138.4 & 0.07 & 0.78 & 1 & & & & & & & & & & & & & \\
\hline 4 & $\mathrm{R} \& \mathrm{D}$ stock & 21.96 & 29.86 & 0.02 & 0.30 & 0.19 & 1 & & & & & & & & & & & & \\
\hline 5 & Total number of alliances & -0.08 & 2.98 & 0.12 & 0.26 & 0.34 & 0.36 & 1 & & & & & & & & & & & \\
\hline 6 & International presence & 0.45 & 0.50 & 0.09 & 0.06 & 0.12 & 0.06 & 0.49 & 1 & & & & & & & & & & \\
\hline 7 & Temporal effect & 7.51 & 4.06 & -0.04 & 0.24 & 0.11 & 0.35 & 0.26 & 0.008 & 1 & & & & & & & & & \\
\hline 8 & Total assets & 31.41 & 42.48 & -0.05 & 0.09 & 0.07 & 0.63 & 0.38 & 0.10 & 0.38 & 1 & & & & & & & & \\
\hline 9 & Number of employees & 0.11 & 0.12 & -0.09 & -0.05 & -0.05 & 0.31 & 0.20 & 0.07 & 0.26 & 0.55 & 1 & & & & & & & \\
\hline 10 & SGA stock & 16.80 & 32.98 & -0.08 & -0.009 & -0.02 & 0.12 & -0.03 & 0.05 & 0.16 & 0.28 & 0.68 & 1 & & & & & & \\
\hline 11 & Total number of subsidiaries & 0.60 & 1.70 & -0.006 & -0.04 & -0.01 & 0.16 & 0.23 & 0.28 & 0.28 & 0.33 & 0.68 & 0.71 & 1 & & & & & \\
\hline 12 & Return on assets & -0.55 & 1.48 & -0.47 & -0.02 & -0.004 & 0.05 & 0.03 & 0.06 & 0.02 & 0.16 & 0.19 & 0.09 & 0.07 & 1 & & & & \\
\hline 13 & $\begin{array}{l}\text { Cash and cash equivalents/Total } \\
\text { assets }\end{array}$ & 0.48 & 0.31 & 0.18 & 0.28 & 0.26 & 0.29 & 0.14 & 0.12 & -0.09 & 0.08 & -0.25 & -0.13 & -0.15 & -0.03 & 1 & & & \\
\hline 14 & Total sales & 16.79 & 34.69 & -0.05 & -0.07 & -0.10 & 0.22 & 0.04 & 0.06 & 0.27 & 0.47 & 0.88 & 0.75 & 0.68 & 0.17 & -0.23 & 1 & & \\
\hline 15 & Foreign to total sales ratio & 0.08 & 0.18 & -0.14 & -0.14 & -0.14 & -0.11 & -0.04 & 0.06 & 0.09 & -0.002 & 0.13 & 0.17 & 0.21 & 0.12 & -0.25 & 0.16 & 1 & \\
\hline 16 & Firm age & 14.70 & 10.78 & -0.06 & -0.09 & -0.14 & -0.10 & -0.05 & -0.14 & 0.28 & 0.05 & 0.39 & 0.14 & 0.19 & 0.01 & -0.34 & 0.29 & -0.02 & 1 \\
\hline
\end{tabular}

Note: Correlations above $|0.05|$ are significant at the 0.05 level. The order of the variables is aligned with the description under "Methodology". 
Table 3.

Generalized linear squares (GLS) regressions: growth of financial resources

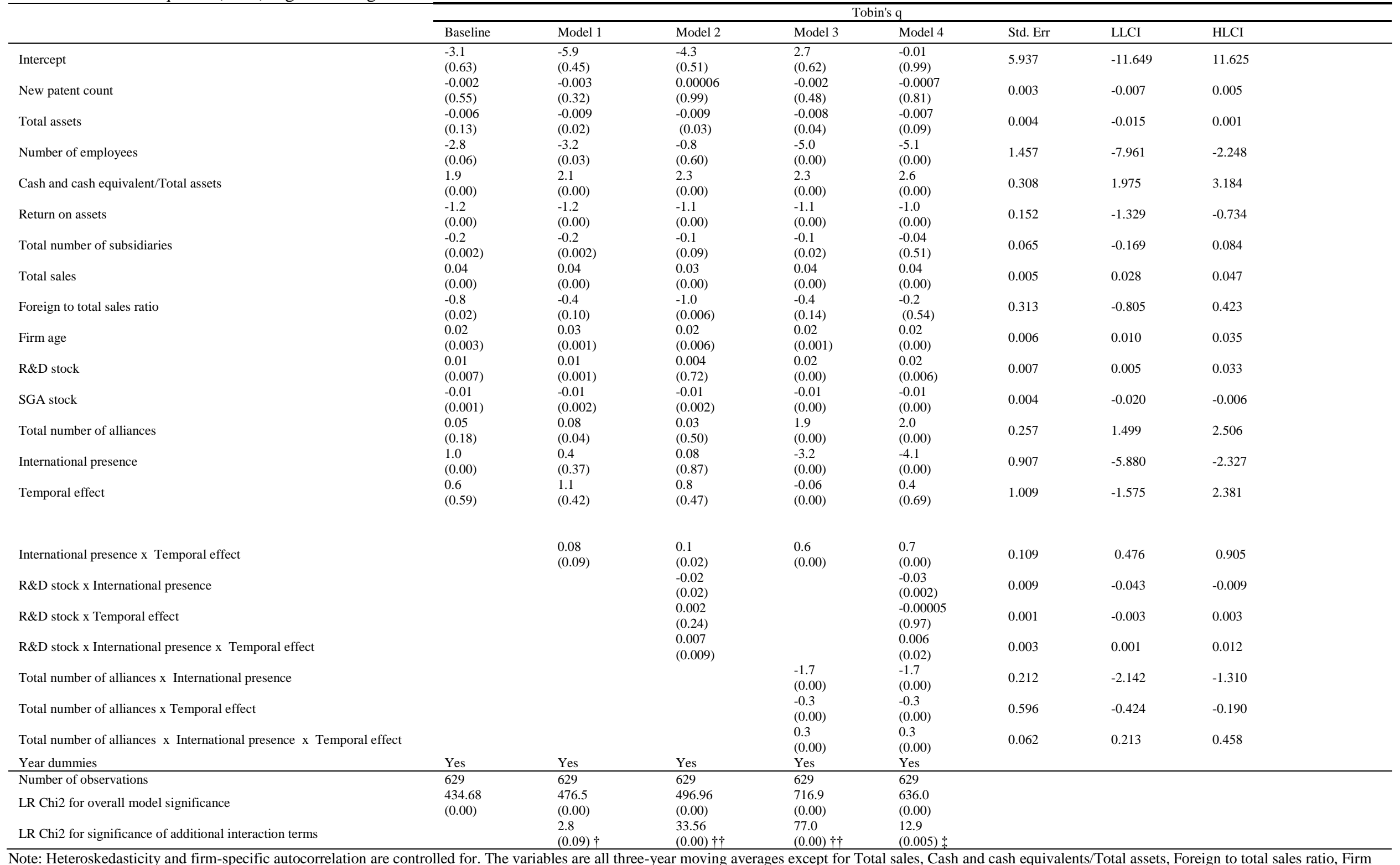

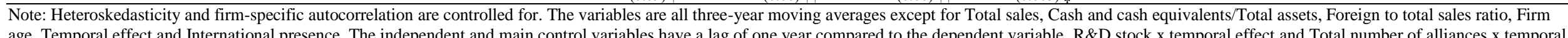

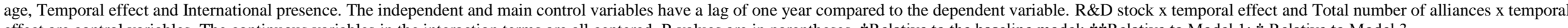
effect are control variables. The continuous variables in the interaction terms are all centered. P-values are in parentheses. $\dagger$ Relative to the baseline model; $\dagger \dagger$ Relative to Model $1 ; \vdots$ Relative to Model 3 
Table 4.

Generalized linear squares (GLS) regressions: growth of intellectual resources (1)

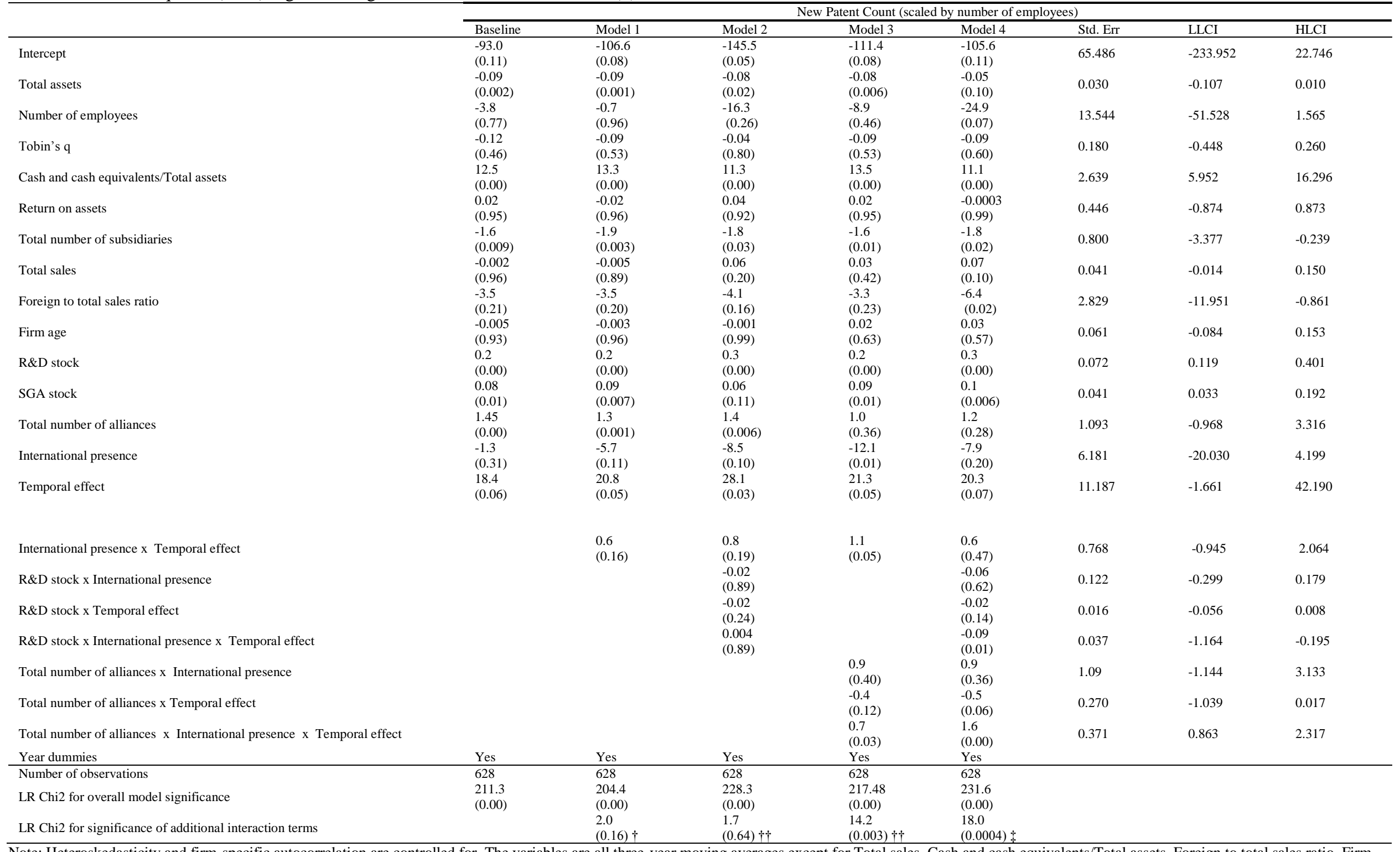

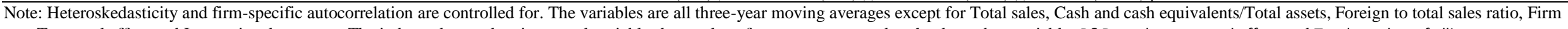

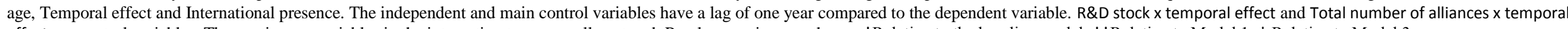
effect are control variables. The continuous variables in the interaction terms are all centered. P-values are in parentheses. $\dagger$ Relative to the baseline model; $\dagger \dagger$ Relative to Model $1 ; \ddagger$ Relative to Model 3 
Table 5.

Generalized linear squares (GLS) regressions: growth of intellectual resources (2)

\begin{tabular}{|c|c|c|c|c|c|c|c|c|}
\hline & & & & tent Citatio & by numbe & ees) & & \\
\hline & Baseline & Model 1 & Model 2 & Model 3 & Model 4 & Std. Err & LLCI & HLCI \\
\hline Intercept & $\begin{array}{l}-449.5 \\
(0.66)\end{array}$ & $\begin{array}{l}-487.6 \\
(0.64)\end{array}$ & $\begin{array}{l}-501.1 \\
(0.72)\end{array}$ & $\begin{array}{l}-539.6 \\
(0.68)\end{array}$ & $\begin{array}{l}-748.4 \\
(0.67)\end{array}$ & 1751.1 & -4180.36 & 2683.65 \\
\hline Total assets & $\begin{array}{l}-1.7 \\
(0.02)\end{array}$ & $\begin{array}{l}-1.7 \\
(0.02)\end{array}$ & $\begin{array}{l}-1.3 \\
(0.10)\end{array}$ & $\begin{array}{l}-1.5 \\
(0.06)\end{array}$ & $\begin{array}{l}-0.8 \\
(0.28)\end{array}$ & 0.784 & -2.379 & 0.693 \\
\hline Number of employees & $\begin{array}{l}207.9 \\
(0.50)\end{array}$ & $\begin{array}{l}216.0 \\
(0.48)\end{array}$ & $\begin{array}{l}3.0 \\
(0.99)\end{array}$ & $\begin{array}{l}33.3 \\
(0.92)\end{array}$ & $\begin{array}{l}-206.1 \\
(0.53)\end{array}$ & 330.3 & -853.541 & 441.245 \\
\hline Tobin's q & $\begin{array}{l}-3.9 \\
(0.41)\end{array}$ & $\begin{array}{l}-3.8 \\
(0.41)\end{array}$ & $\begin{array}{l}-0.8 \\
(0.90)\end{array}$ & $\begin{array}{l}-2.4 \\
(0.64)\end{array}$ & $\begin{array}{l}-2.4 \\
(0.70)\end{array}$ & 6.126 & -14.408 & 9.605 \\
\hline Cash and cash equivalents/Total assets & $\begin{array}{l}379.7 \\
(0.00)\end{array}$ & $\begin{array}{l}380.4 \\
(0.00)\end{array}$ & $\begin{array}{l}289.8 \\
(0.00)\end{array}$ & $\begin{array}{l}356.5 \\
(0.00)\end{array}$ & $\begin{array}{l}291.9 \\
(0.00)\end{array}$ & 62.962 & 168.463 & 415.270 \\
\hline Return on assets & $\begin{array}{l}-4.8 \\
(0.67)\end{array}$ & $\begin{array}{l}-4.7 \\
(0.67)\end{array}$ & $\begin{array}{l}-0.6 \\
(0.97)\end{array}$ & $\begin{array}{l}-2.5 \\
(0.84)\end{array}$ & $\begin{array}{l}-2.6 \\
(0.88)\end{array}$ & 16.418 & -34.749 & 29.608 \\
\hline Total number of subsidiaries & $\begin{array}{l}-12.9 \\
(0.41)\end{array}$ & $\begin{array}{l}-13.8 \\
(0.40)\end{array}$ & $\begin{array}{l}-20.1 \\
(0.30)\end{array}$ & $\begin{array}{l}-6.2 \\
(0.72)\end{array}$ & $\begin{array}{l}-14.0 \\
(0.47)\end{array}$ & 19.468 & -52.178 & 24.137 \\
\hline Total sales & $\begin{array}{l}-0.96 \\
(0.29)\end{array}$ & $\begin{array}{l}-0.95 \\
(0.28)\end{array}$ & $\begin{array}{l}-0.7 \\
(0.41)\end{array}$ & $\begin{array}{l}-0.4 \\
(0.73)\end{array}$ & $\begin{array}{l}-0.2 \\
(0.79)\end{array}$ & 0.759 & -1.687 & 1.290 \\
\hline Foreign to total sales ratio & $\begin{array}{l}-189.0 \\
(0.006)\end{array}$ & $\begin{array}{l}-188.0 \\
(0.006)\end{array}$ & $\begin{array}{l}-171.1 \\
(0.02)\end{array}$ & $\begin{array}{l}-171.1 \\
(0.02)\end{array}$ & $\begin{array}{r}-178.9 \\
(0.02)\end{array}$ & 78.315 & -332.361 & -25.372 \\
\hline Firm age & $\begin{array}{l}-1.6 \\
(0.24)\end{array}$ & $\begin{array}{l}-1.6 \\
(0.23)\end{array}$ & $\begin{array}{l}-1.2 \\
(0.46)\end{array}$ & $\begin{array}{l}-0.7 \\
(0.62)\end{array}$ & $\begin{array}{l}-0.3 \\
(0.82)\end{array}$ & 1.483 & -3.239 & 2.576 \\
\hline$R \& D$ stock & $\begin{array}{l}2.0 \\
(0.002)\end{array}$ & $\begin{array}{l}2.0 \\
(0.001)\end{array}$ & $\begin{array}{l}2.7 \\
(0.09)\end{array}$ & $\begin{array}{l}1.8 \\
(0.005)\end{array}$ & $\begin{array}{l}2.6 \\
(0.09)\end{array}$ & 1.542 & -0.414 & 5.632 \\
\hline SGA stock & $\begin{array}{l}1.4 \\
(0.09)\end{array}$ & $\begin{array}{l}1.4 \\
(0.09)\end{array}$ & $\begin{array}{l}1.5 \\
(0.08)\end{array}$ & $\begin{array}{l}1.4 \\
(0.13)\end{array}$ & $\begin{array}{l}1.7 \\
(0.06)\end{array}$ & 0.914 & -0.092 & 3.493 \\
\hline Total number of alliances & $\begin{array}{l}58.0 \\
(0.00)\end{array}$ & $\begin{array}{l}57.4 \\
(0.00)\end{array}$ & $\begin{array}{l}48.6 \\
(0.001)\end{array}$ & $\begin{array}{l}38.7 \\
(0.39)\end{array}$ & $\begin{array}{l}34.7 \\
(0.42)\end{array}$ & 42.761 & -49.142 & 118.489 \\
\hline International presence & $\begin{array}{l}-51.9 \\
(0.13)\end{array}$ & $\begin{array}{l}-63.5 \\
(0.50)\end{array}$ & $\begin{array}{l}103.0 \\
(0.43)\end{array}$ & $\begin{array}{l}-140.8 \\
(0.40)\end{array}$ & $\begin{array}{l}82.4 \\
(0.63)\end{array}$ & 169.787 & -250.388 & 415.165 \\
\hline Temporal effect & $\begin{array}{l}120.1 \\
(0.50)\end{array}$ & $\begin{array}{l}126.9 \\
(0.50)\end{array}$ & $\begin{array}{l}119.2 \\
(0.62)\end{array}$ & $\begin{array}{l}124.7 \\
(0.58)\end{array}$ & $\begin{array}{l}147.2 \\
(0.62)\end{array}$ & 298.855 & -438.585 & 732.903 \\
\hline International presence $\mathrm{x}$ Temporal effect & & $\begin{array}{l}1.7 \\
(0.87)\end{array}$ & $\begin{array}{l}-23.7 \\
(0.15)\end{array}$ & $\begin{array}{l}6.9 \\
(0.73)\end{array}$ & $\begin{array}{l}-24.3 \\
(0.25)\end{array}$ & 21.051 & -65.553 & 16.966 \\
\hline$R \& D$ stock $x$ International presence & & & $\begin{array}{l}7.8 \\
(0.006)\end{array}$ & & $\begin{array}{l}7.3 \\
(0.009)\end{array}$ & 2.795 & 1.825 & 12.781 \\
\hline$R \& D$ stock $x$ Temporal effect & & & $\begin{array}{l}-0.4 \\
(0.29)\end{array}$ & & $\begin{array}{l}-0.5 \\
(0.16)\end{array}$ & 0.338 & -1.141 & 0.183 \\
\hline$R \& D$ stock $x$ International presence $x$ Temporal effect & & & $\begin{array}{l}-1.4 \\
(0.08)\end{array}$ & & $\begin{array}{l}-2.2 \\
(0.01)\end{array}$ & 0.859 & -3.834 & -0.469 \\
\hline Total number of alliances $x$ International presence & & & & $\begin{array}{l}29.7 \\
(0.47)\end{array}$ & $\begin{array}{l}17.5 \\
(0.66)\end{array}$ & 39.711 & -60.348 & 95.315 \\
\hline Total number of alliances $x$ Temporal effect & & & & $\begin{array}{l}-6.1 \\
(0.56)\end{array}$ & $\begin{array}{l}-4.8 \\
(0.59)\end{array}$ & 8.894 & -22.270 & 12.592 \\
\hline Total number of alliances $\mathrm{x}$ International presence $\mathrm{x}$ Temporal effect & & & & $\begin{array}{l}7.8 \\
(0.49)\end{array}$ & $\begin{array}{l}16.5 \\
(0.13)\end{array}$ & 10.894 & -4.894 & 37.811 \\
\hline Year dummies & Yes & Yes & Yes & Yes & Yes & & & \\
\hline Number of observations & 628 & 628 & 628 & 628 & 628 & & & \\
\hline LR Chi2 for overall model significance & $\begin{array}{l}159.1 \\
(0.00)\end{array}$ & $\begin{array}{l}154.17 \\
(0.00)\end{array}$ & $\begin{array}{l}139.9 \\
(0.00)\end{array}$ & $\begin{array}{l}144.5 \\
(0.00)\end{array}$ & $\begin{array}{l}151.4 \\
(0.00)\end{array}$ & & & \\
\hline LR Chi2 for significance of additional interaction terms & & $\begin{array}{l}0.03 \\
(0.87) \dagger\end{array}$ & $\begin{array}{l}7.6 \\
(0.02) \dagger \dagger\end{array}$ & $\begin{array}{l}3.8 \\
(0.28) \dagger \dagger\end{array}$ & $\begin{array}{l}5.7 \\
(0.13) \dagger\end{array}$ & & & \\
\hline
\end{tabular}

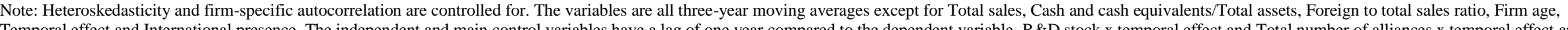

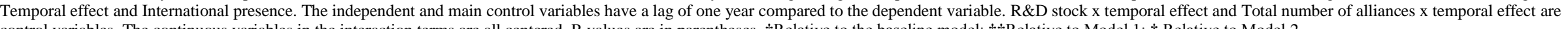
control variables. The continuous variables in the interaction terms are all centered. P-values are in parentheses. $\dagger$ Relative to the baseline model; $\dagger \dagger$ Relative to Model $1 ; \uparrow$ Relative to Model 2 


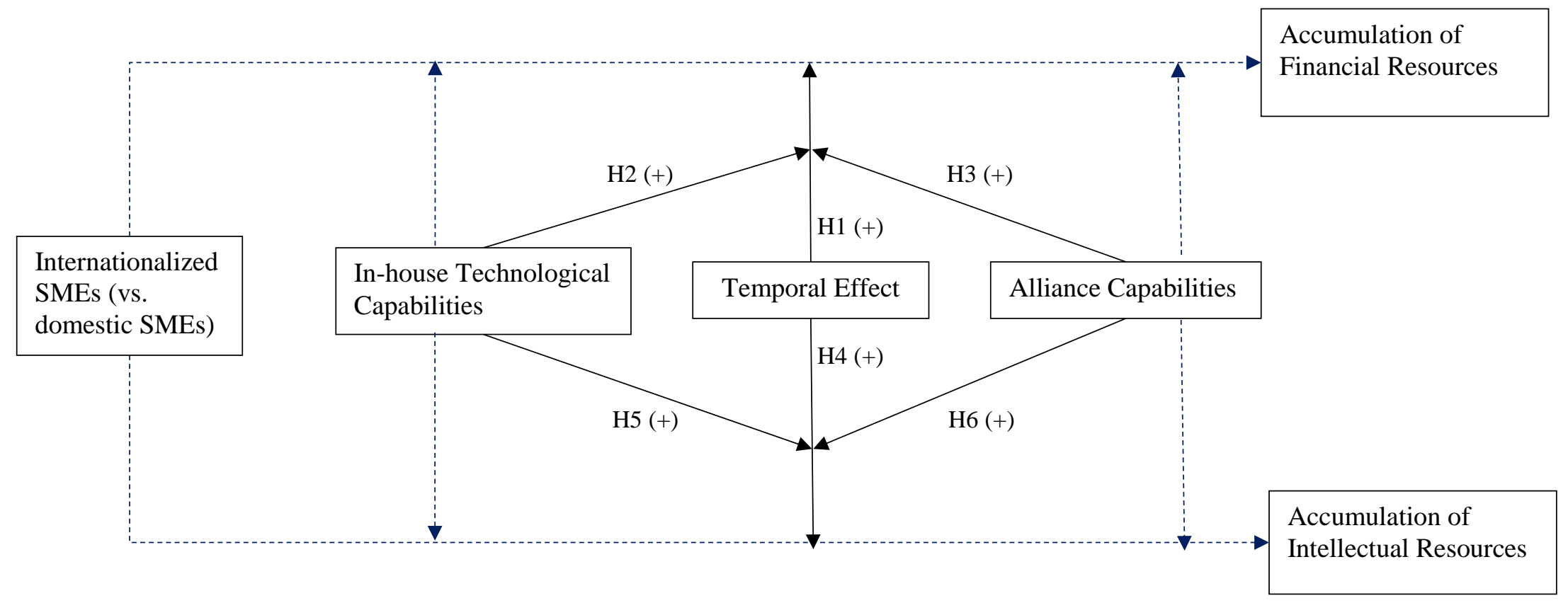

$\mathrm{H} 7$ (not displayed) states that alliance capabilities are more important than in-house technological capabilities in long-term resource accumulation.

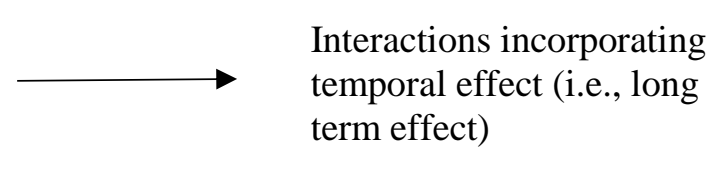

Fig. 1. A Diagram of the Analytical Model
Main effects or interactions

without incorporating temporal effect 

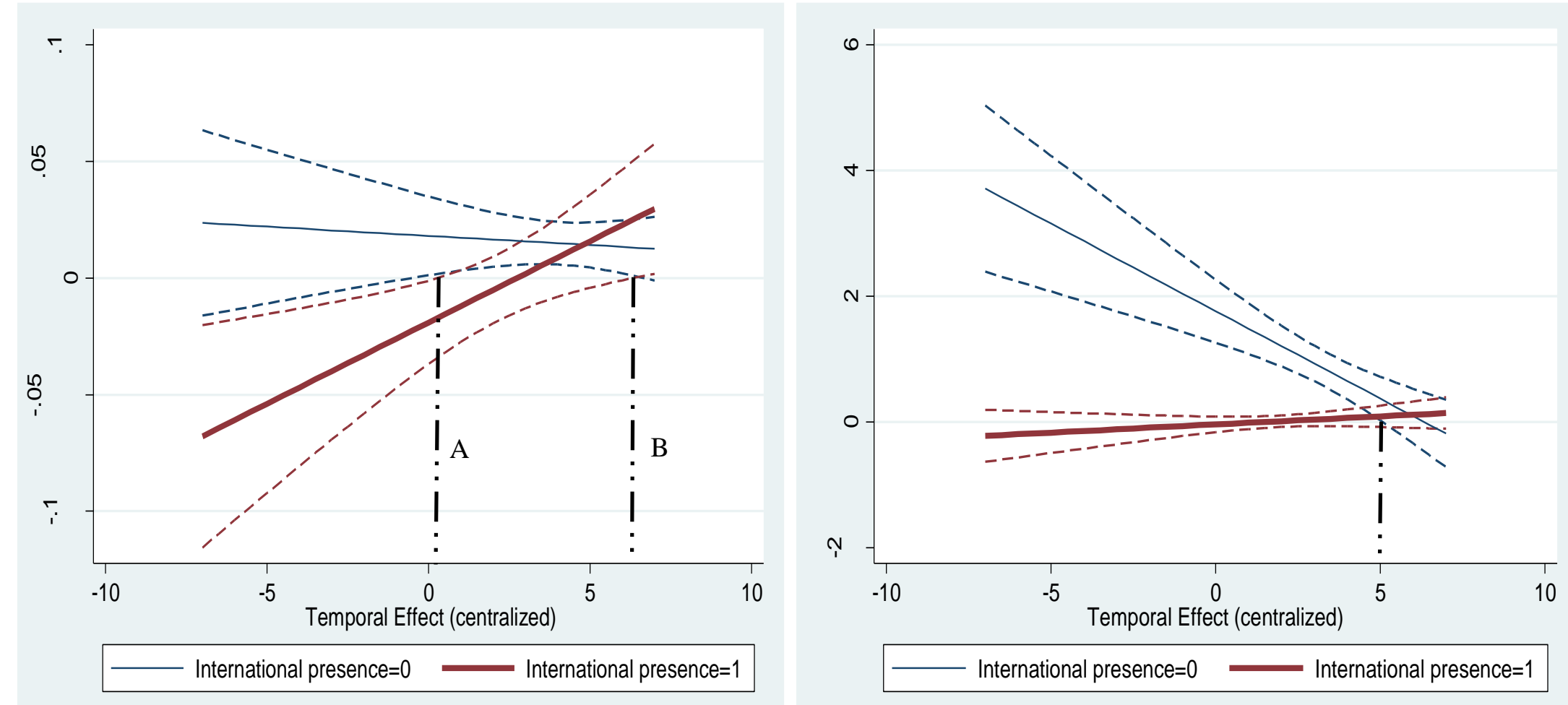

Note: the dotted lines indicate the $95 \%$ confidence intervals. Only if the two dotted lines reflecting the confidence interval are both either above or below the horizontal zeroline, the interaction effect is significant.

Left graph: The marginal effect of R\&D stock on Tobin's q is only positive and significant in the range between A and B for domestic SMEs; for internationalized SMEs, the marginal effect is negative and significant in the range to the left of vertical A line but positive and significant in the range to the right of vertical B line.

Right graph: The marginal effect of alliances on Tobin's q is positive and significant for domestic SMEs only in the range to the left of the vertical line; for internationalized SMEs, the marginal effect is not significant from zero.

Fig. 2. The marginal impact of R\&D stock and alliances on financial resource growth (Tobin's q) 

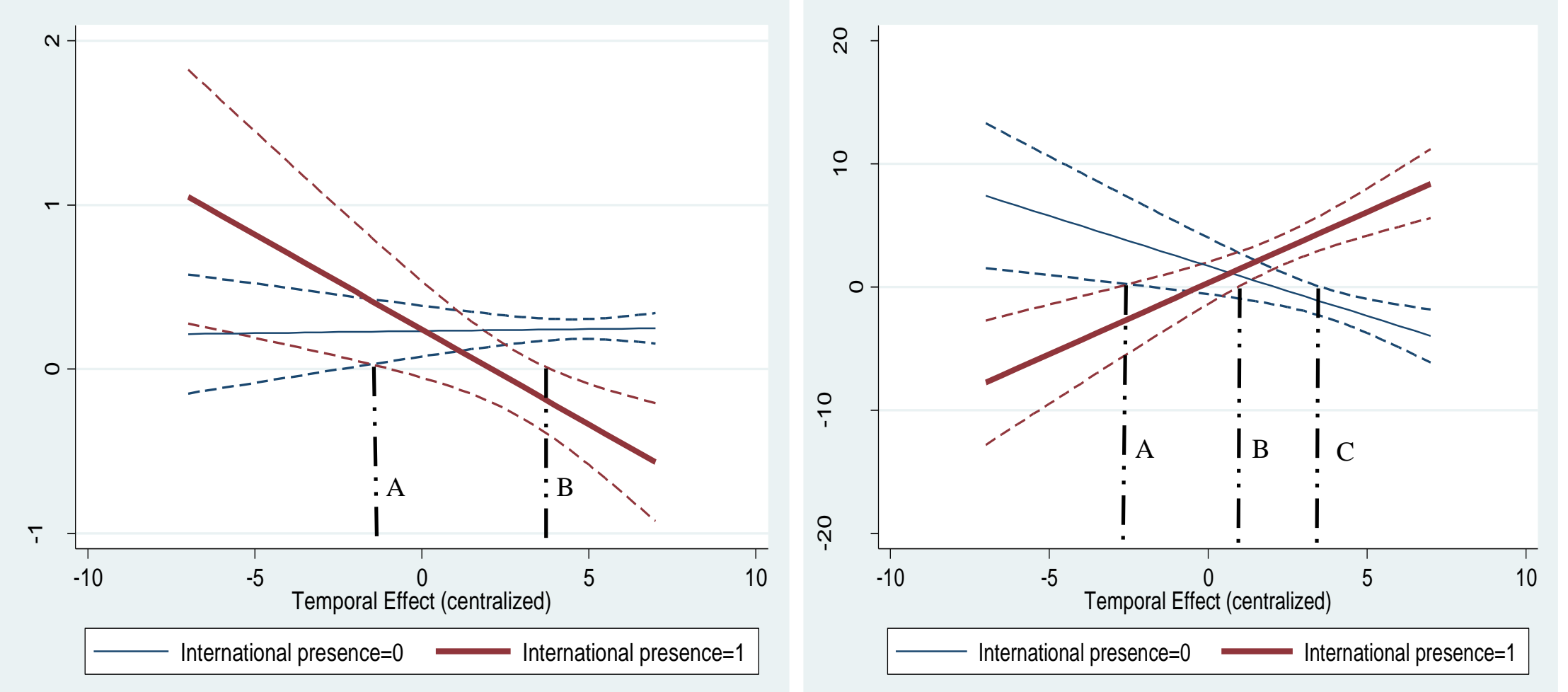

Note: the dotted lines indicate the $95 \%$ confidence intervals. Only if the two dotted lines reflecting the confidence interval are both either above or below the horizontal zeroline, the interaction effect is significant.

Left graph: The marginal effect of R\&D stock on new patent count is only positive and significant in the range to the right of vertical A line for domestic SMEs; for internationalized SMEs, the marginal effect is positive and significant in the range to the left of vertical A line but negative and significant in the range to the right of vertical B line.

Right graph: For domestic SMEs, the marginal effect of alliances on new patent count is positive and significant in the range to the left of the vertical A line but negative and significant in the range to the right of vertical $\mathrm{C}$ line; for internationalized SMEs, the marginal effect is negative and significant in the range to the left of vertical A line but positive and significant in the range to the right of vertical B line.

Fig. 3. The marginal impact of $R \& D$ stock and alliances on intellectual resource growth (new patent count scaled by number of employees) 

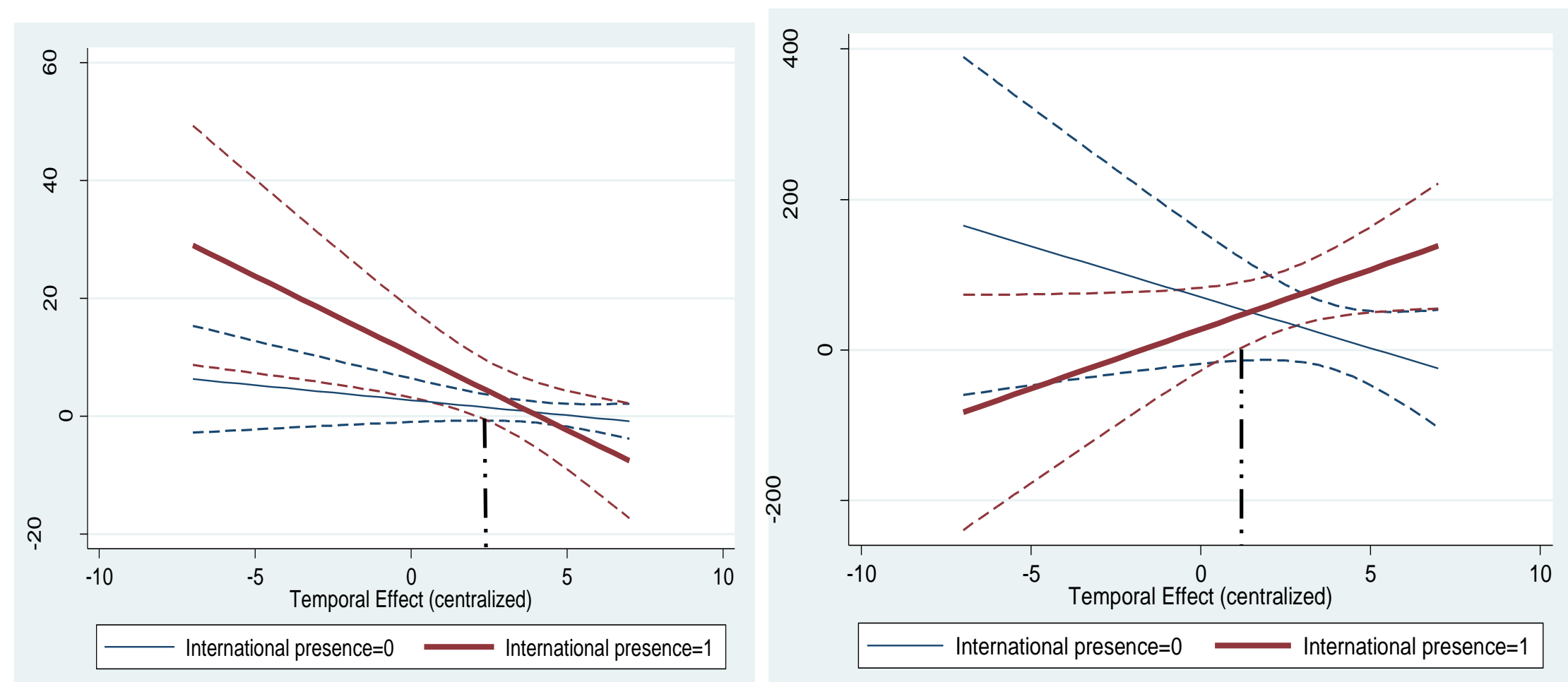

Note: the dotted lines indicate the $95 \%$ confidence intervals. Only if the two dotted lines reflecting the confidence interval are both either above or below the horizontal zeroline, the interaction effect is significant.

Left graph: The marginal effect of R\&D stock on new patent citations is not significantly different from zero for domestic SMEs; for internationalized SMEs, the marginal effect is positive and significant in the range to the left of the vertical line but insignificantly different from zero in the range to the right of the vertical line.

Right graph: The marginal effect of alliances on new patent citations is not significantly different from zero for domestic SMEs; for internationalized SMEs, the marginal effect is not significant from zero in the range to the left of the vertical line but positive and significant in the range to the right of the vertical line.

Fig. 4. The marginal impact of R\&D stock and alliances on intellectual resource growth (new patent citations scaled by number of employees) 
Appendix. Variables, measures and references

\begin{tabular}{|c|c|c|c|c|}
\hline & Variables & Proxies/Measures & Values & References \\
\hline 1. & $\begin{array}{l}\text { Financial } \\
\text { resource growth }\end{array}$ & Tobin's q & $\begin{array}{l}\text { The market value of assets } \\
\text { divided by the book value } \\
\text { of assets (continuous) }\end{array}$ & $\begin{array}{l}\text { Chung \& Pruitt (1994), } \\
\text { Hirschey \& Weygandt } \\
\text { (1985), Smirlock, } \\
\text { Gilligan \& Marshall } \\
\text { (1984), , Whited (2001) }\end{array}$ \\
\hline 2. & $\begin{array}{l}\text { Intellectual } \\
\text { resource growth }\end{array}$ & $\begin{array}{c}\text { (1) new patent count; (2) new } \\
\text { patent citations }\end{array}$ & $\begin{array}{c}\text { Scaled by number of } \\
\text { employees } \\
\text { (continuous) }\end{array}$ & $\begin{array}{l}\text { Fabrizio \& Thomas } \\
\text { (2012) }\end{array}$ \\
\hline 3. & $\begin{array}{l}\text { In-house } \\
\text { technological } \\
\text { capabilities }\end{array}$ & R\&D stock & $\begin{array}{c}\text { The total value of the } \\
\text { current year R\&D } \\
\text { expenditure plus R\&D } \\
\text { spending from the four } \\
\text { previous years depreciated } \\
\text { at fifteen percent } \\
\text { (continuous) }\end{array}$ & Berry (2006) \\
\hline 4. & $\begin{array}{c}\text { Alliance } \\
\text { capabilities }\end{array}$ & Total number of alliances & $\begin{array}{c}\text { Total number of alliances } \\
\text { (continuous) }\end{array}$ & $\begin{array}{c}\text { Rothaermel \& Deeds } \\
\text { (2006) }\end{array}$ \\
\hline 5. & $\begin{array}{l}\text { International } \\
\text { presence }\end{array}$ & $\begin{array}{c}\text { Internationalized SMEs have at } \\
\text { least one foreign subsidiary or } \\
\text { a foreign alliance as opposed to } \\
\text { domestic SMEs. }\end{array}$ & 0 or 1 & \\
\hline 6. & Temporal effect & $\begin{array}{c}\text { The integer value from } 0 \text { to } 14 \\
\text { with } 0 \text { being } 1987 \text {, the starting } \\
\text { year, and } 14 \text { being } 2001 \text {, the } \\
\text { last year during our observation } \\
\text { period }\end{array}$ & Continuous & \\
\hline 7. & $\begin{array}{l}\text { Physical } \\
\text { resources }\end{array}$ & Total assets & Continuous & \\
\hline 8. & $\begin{array}{c}\text { Human } \\
\text { resources }\end{array}$ & Number of employees & Continuous & Lockett et al. (2011) \\
\hline 9. & $\begin{array}{l}\text { Non- } \\
\text { technological } \\
\text { capabilities }\end{array}$ & $\begin{array}{c}\text { Selling, general, and } \\
\text { administrative (SGA) stock }\end{array}$ & $\begin{array}{c}\text { The firm's current year } \\
\text { SGA expenditure, plus that } \\
\text { of the previous two years } \\
\text { depreciated at a fifty } \\
\text { percent rate (continuous) }\end{array}$ & $\begin{array}{l}\text { Hirschey \& Weygandt } \\
\qquad(1985)\end{array}$ \\
\hline 10 & $\begin{array}{l}\text { Number of } \\
\text { subsidiaries }\end{array}$ & Number of subsidiaries & Continuous & \\
\hline 11. & $\begin{array}{l}\text { Return on assets } \\
(\mathrm{ROA})\end{array}$ & Return on assets (ROA) & Continuous & \\
\hline 12. & $\begin{array}{l}\text { Cash and cash } \\
\text { equivalents / } \\
\text { Total assets }\end{array}$ & $\begin{array}{c}\text { Cash and cash equivalents / } \\
\text { Total assets }\end{array}$ & Continuous & \\
\hline 13. & Total sales & Total sales & Continuous & \\
\hline 14. & $\begin{array}{c}\text { Foreign to total } \\
\text { sales ratio }\end{array}$ & Foreign to total sales ratio & Continuous & \\
\hline 15. & Firm age & $\begin{array}{c}\text { The number of years since the } \\
\text { founding of a firm }\end{array}$ & Continuous & \\
\hline 16 & Year dummies & Year dummies $(1988-2001)$ & 0 or 1 & \\
\hline
\end{tabular}

